\title{
Vertebrate tracksites in the Obernkirchen Sandstone (late Berriasian, Early Cretaceous) of northwest Germany - their stratigraphical, palaeogeographical, palaeoecological, and historical context
}

\author{
Jahn J. Hornung • Annina Böhme \\ Torsten van der Lubbe $\cdot$ Mike Reich • \\ Annette Richter
}

Received: 26 November 2010/Accepted: 25 October 2011/Published online: 14 March 2012

(C) The Author(s) 2012. This article is published with open access at Springerlink.com

\begin{abstract}
The northern German Lower Cretaceous Bückeberg Formation yields numerous dinosaur tracksites, some of which have produced material of impressive quality. Stratigraphically, the localities are concentrated in the Obernkirchen Sandstone, a thin subunit within this formation. The Obernkirchen Sandstone represents mainly a sandy barrier to back-barrier and lagoonal setting within a limnic deltaic facies complex, which was deposited during the late Berriasian (Cypridea alta formosa ostracod subzone) in the southeast of the Lower Saxony Basin, northwest Germany. A few tracksites occur more proximally in coeval fluvial deposits. Dinosaur footprint assemblages were left by ornithopods, theropods, sauropods, ankylosaurs, and small, bipedal ornithischians. Other vertebrate tracks are those of turtles and, possibly, crocodilians. Due to the decrease in sandstone quarrying in recent decades, many old tracksites
\end{abstract}

J. J. Hornung $(\bowtie) \cdot$ A. Böhme

Geowissenschaftliches Zentrum, Abt. Geobiologie,

Georg-August-Universität Göttingen, Goldschmidtstr. 3,

37077 Göttingen, Germany

e-mail: jhornun@gwdg.de

A. Böhme

e-mail: aboehme@gwdg.de

T. van der Lubbe $\cdot$ A. Richter

Niedersächsisches Landesmuseum Hannover,

Willy-Brandt-Allee 5, 30169 Hannover, Germany

e-mail: DragonsClaw@gmx.net

A. Richter

e-mail: Annette.Richter@nlm-h.niedersachsen.de

\section{Reich ( $\square)$}

Geowissenschaftliches Zentrum, Museum, Sammlungen

and Geopark, Georg-August-Universität Göttingen,

Goldschmidtstr. 1-5, 37077 Göttingen, Germany

e-mail: mreich@gwdg.de are inaccessible today. Additionally, historical descriptions of the tracks were of highly variable quality and often published in remote and today nearly unobtainable sources. Here we provide a catalogue of 13 tracksites compiled from the literature and some new observations. Of these 13 tracksites, only five are still accessible and currently under study. Descriptions of each locality are provided, with a comprehensive compilation of existing data on lithofacies, stratigraphy, palaeogeography and palaeoecology of the Obernkirchen Sandstone and equivalent strata. A short review of the track-bearing lithofacies assemblage indicates that the outcrop areas have distinctly different facies and environments, and, therefore, track-bearing horizons can only be correlated stratigraphically between adjacent outcrops. For this reason, the identification of a megatracksite in the Obernkirchen Sandstone is currently regarded as premature and uncertain.

Keywords Vertebrate tracks - Dinosauria - Cretaceous . Berriasian · Obernkirchen · Münchehagen · Germany

Kurzfassung Die unterkretazische Bückeberg-Formation Nordwest-Deutschlands ist reich an Fundstellen von Dinosaurierfährten, von denen einige hervorragend erhaltenes Material lieferten. Diese Fundstellen sind stratigraphisch auf ein geringmächtiges Intervall, den ObernkirchenSandstein, konzentriert. Der Obernkirchen-Sandstein repräsentiert eine sandige Barrieren- und Lagunen-Fazies innerhalb eines limnisch-deltaischen Fazieskomplexes, der während des späten Berriasiums (Cypridea alta formosa Ostrakoden-Subzone) im Südosten des Niedersächsischen Beckens abgelagert wurde. Einige Fährtenfundstellen liegen auch in etwas proximaleren, gleichaltrigen, fluviatilen Ablagerungen. Erzeuger der Dinosaurierfährten waren Ornithopoden, Theropoden, Sauropoden, Ankylosaurier 
sowie kleine, bipede Ornithischia. Weitere WirbeltierFährten wurden von Schildkröten und möglicherweise Krokodilen hinterlassen. Aufgrund des Rückgangs im Sandstein-Abbau im Verlauf der vergangenen Jahrzehnte sind viele der alten Fährten-Fundstellen heute nicht mehr aufgeschlossen. Historische Beschreibungen sind von unterschiedlicher Qualität und häufig nur in schwer erhältlichen Quellen publiziert. Hier präsentieren wir einen Katalog mit 13 Fundstellen, zusammengestellt aus Literaturquellen und neuen Untersuchungen. Nur fünf Fundstellen sind heute noch zugänglich und derzeit Gegenstand weiterer Forschungen. Sämtliche Fundstellen werden vorgestellt und der Kenntnisstand über Lithofazies, Stratigraphie, Paläogeographie und Paläoökologie des Obernkirchener Sandsteins zusammengefasst. Lithofazies-Daten zeigen, dass eine feinstratigraphische Korrelation individueller Horizonte innerhalb des Sandstein-Komplexes nur zwischen sehr eng benachbarten Aufschlüssen möglich ist und deutliche Faziesunterschiede zwischen den Fährtenvorkommen bestehen. Daher erscheint die derzeitige Datengrundlage als nicht hinreichend, um den ObernkirchenSandstein in seiner Gesamtheit als Megatracksite zu charakterisieren.

Schlüsselwörter Wirbeltier-Fährten · Dinosauria · Kreide · Berriasium · Obernkirchen · Münchehagen · Deutschland

\section{Introduction}

The Berriasian Bückeberg Formation is well-known for its wealth of dinosaur tracks (Ballerstedt 1905; Dietrich 1927; Lehmann 1978), but their documentation is mostly confined to isolated specimens or localities. Important discoveries of the last two decades are mostly reported in general overviews or abstracts (Wings et al. 2005a; Lehmann 2006; Lehmann et al. 2006; A. Richter et al. 2007; U. Richter et al. 2007; Richter et al. 2009; Richter 2007; Böhme et al. 2009; van der Lubbe et al. 2009).

Nearly all tracksites from the Bückeberg Formation are located stratigraphically within the Obernkirchen Sandstone, a thin subunit exposed in the northern and western vicinities of Hannover. At least since early medieval times, this sandstone has been a valued dressing stone and building material. Intensive quarrying since the 11th century AD led to the use of the nearly pure quartzose sandstone in hundreds of buildings and monuments across northern Germany, Europe, and in places as far abroad as Jakarta, Indonesia (Hamm 1938; Graupner 1977; Harnack 1989; Broschinski 2004). Since the beginning of the 19th century, this formation became increasingly well-known as a lagerstaette for rare but well-preserved Cretaceous vertebrates, including turtles, crocodiles, and dinosaurs (e.g. Roemer 1836; von Meyer 1841, 1857, 1859; von Meyer in Dunker 1846).

Although extremely abundant and probably known to quarry workers for centuries, reliable accounts of dinosaur tracks were not reported before the middle of the 19th century. According to Grabbe (1881), the mining supervisor Heidtmeier reported the occurrence of a trail of consecutive tracks more than $100 \mathrm{~m}$ long which was uncovered in a quarry near Wendthagen in the 1850s. Unfortunately, there are no other records of this find.

In 1879, the first dinosaur tracks reported from Germany rather sneaked into the scientific record. At the December meeting of the Deutsche Geologische Gesellschaft (German Geological Society), held on 3 December 1879, in Berlin, Wilhelm Hauchecorne presented a letter and a drawing by mining engineer Fritz F. von Dücker, in which he reported the discovery of "bird tracks" in the Bad Rehburg area. At the same meeting, Wilhelm Dames commented that these tracks were very similar to those from the English Wealden, which had been identified as dinosaur tracks shortly before. Both contributions consisted of a single sentence each, included in the published proceedings of the meeting (Dames in Beyrich et al. 1879; Hauchecorne in Beyrich et al. 1879).

The geologist Carl Struckmann was the first researcher to provide a scientific description of these tracks. During the summer of 1879 , more tracks were found at Wölpinghausen (Rehburg mountains, see locality 4 below) and immediately vividly discussed in local press reports (Anonymous 1879a, b). These early discussions, led mostly by Struckmann, centred around a "bird-like" animal as a potential trackmaker. This view was not left unchallengedin fact, the ornithologist Wilhelm Pralle suggested the tridactyl imprints had been made by the mani (!) of giant anurans (Anonymous 1879b). In 1880, Struckmann substantiated his results and published the first papers on the "Ornithoidichnites", referring them to the dinosaur Iguanodon (Struckmann 1880a, b).

To corroborate his identification, Struckmann sent a gypsum cast of one of the tracks to Louis Dollo, in Brussels, who was the most important authority on Iguanodon at the time, and was studying the famous "herd" of this dinosaur found at the Bernissart coal mine in 1878. Dollo (1883: 113) reported a perfect match of this track with the pedal skeleton of a specimen he identified as Iguanodon mantelli.

At least two specimens of Struckmann's material are still preserved in the Niedersächsisches Landesmuseum, Hannover. One right pes impression of a large ornithopod (NLMH 105.747, Fig. 1) can be identified as the specimen which was deemed an exception by him, as he believed it was tetradactyl instead of tridactyl (Struckmann 1880a: 99, 


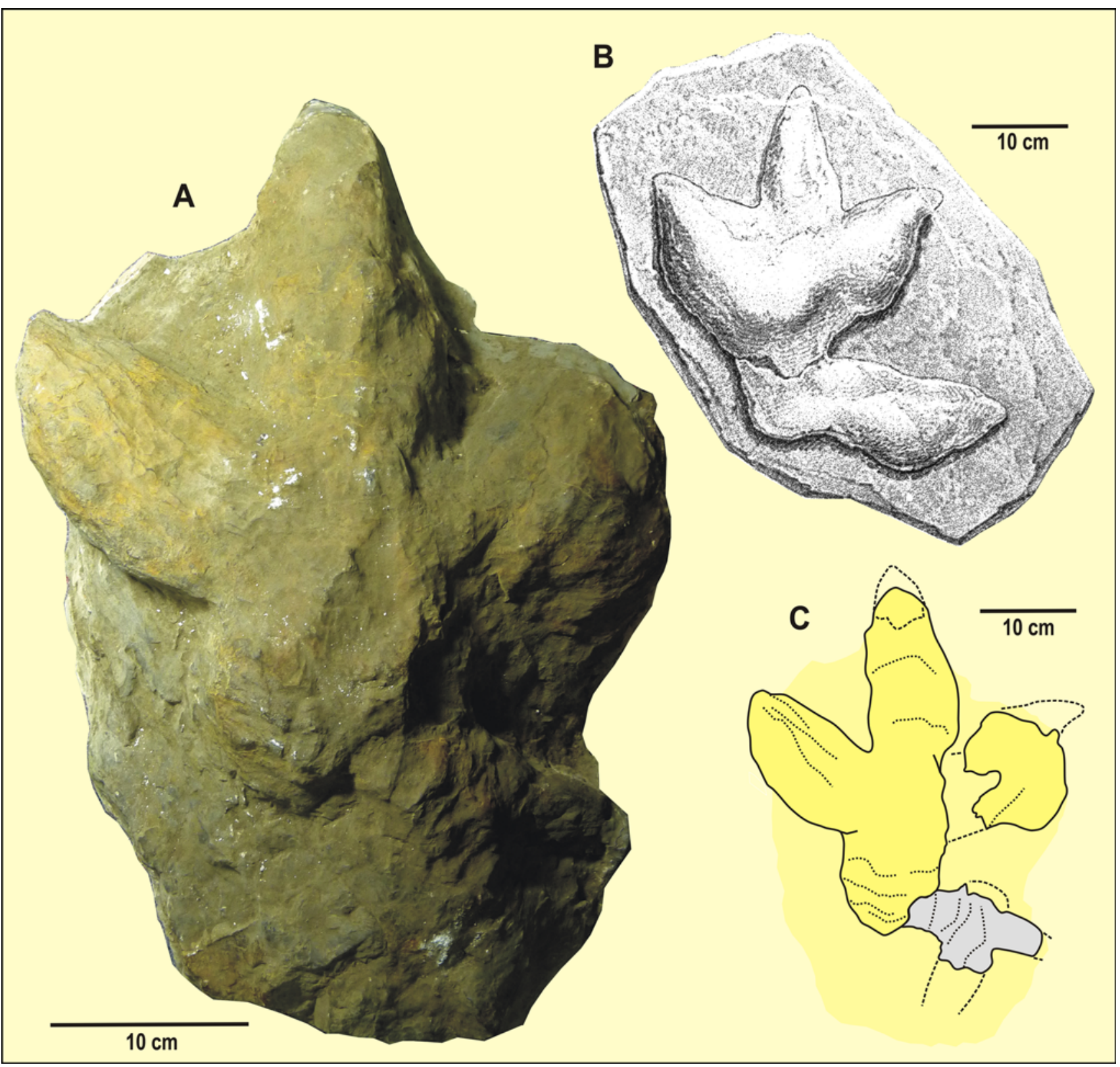

Fig. 1 Right pes impression (hypichnial relief) of a large ornithopod (NLMH 105.747), Bückeberg Formation, Obernkirchen Member, Obernkirchen Sandstone. Most probably an original specimen of Struckmann (1880a), collected in the summer of 1879 from the quarry of A. Spörl near Wölpinghausen, Rehburg Mountains, Lower Saxony (locality 4). This is, historically, the first footprint to be identified as having been left by a dinosaur in Germany and is still preserved in a

pl. V, fig. 1; here Fig. 1b). This identification of the specimen seems to be well substantiated, although the figure by Struckmann was quite schematic in some details and the proportions of the footprint and the supposed "hallux" seems not to have been depicted entirely correctly by him. Subsequent studies (e.g. Grabbe 1883; Koken 1887; Ballerstedt 1914; Dietrich 1927) doubted the interpretation of the "hallux". The specimen as preserved today public collection. a Specimen as preserved today; b Specimen as drawn by Struckmann (1880a: pl. V, fig. 1). The structure below the footprint was interpreted as a hallux impression by C. Struckmann. This interpretation was rejected by subsequent scientists; c New interpretation of the specimen (drawing). The grey-shaded structure is interpreted as the remains of a much smaller tridactyl(?) footprint, over-stepped by the ornithopod heading in the opposite direction

(Fig. 1a) supports the observation by Ballerstedt (1914) that the "first digit" is in fact a poorly preserved footprint over-stepped and deformed by the large, typically tridactyl, ornithopod footprint (Fig. 1c). It is the historically oldest find of a dinosaur track from Germany still preserved in a public collection. Identification of the second specimen (NLMH 105.746) is not as straightforward, because it cannot be directly identified as one of those depicted by 
Struckmann. However, he collected far more material than he figured, and the size, proportions, and morphological details of the specimen suggest that it belonged to a trackway from which he figured two other, subsequent footsteps, preserved on a single sandstone slab which is currently lost (Struckmann 1880a: 98-99, pl. IV, fig. 1, 1880b: 127, pl. IV).

Struckmann's discoveries were followed shortly by those of Grabbe (1881, 1883), who identified dinosaur tracks in many localities in the Bückeberge and Harrl areas.

Over the following decades, numerous reports were published of tracksites in the outcrop area of the Obernkirchen Sandstone. Most of these appeared in hard-toobtain local journals, some of them even in newspapers, and they are almost exclusively written in the German language. Additionally, in many cases, the original material was considered lost, hampering modern revisions (Haubold 1971, 1974, 1984; Lockley 2000; Thulborn 2001).

The historical collection of the Gymnasium Adolfinum Bückeburg and the Max Ballerstedt private collection are highly important in investigations of Berriasian dinosaur tracks from Germany. Although a few specimens from these collections date back to the 1840s, the bulk of the material was collected between ca 1900 and 1940 by the teacher and amateur palaeontologist Max Ballerstedt (1857-1945). The collection includes a large number of footprints (mostly natural casts), some of which were original specimens of Ballerstedt's publications (see also Thulborn 2001). However, after Ballerstedt's death in 1945, the collection suffered from lack of care and attendance shortly after World War II (Probst and Windolf 1993; Hornung and Reich 2007). Most of what survived is stored in the collections of the Geoscience Centre of the University of Göttingen. A detailed inventory or catalogue of the Ballerstedt collection is currently incomplete. In an ongoing project, this gap is to be filled and many of Ballerstedt's specimens, thought to be lost, have recently been located and are, in fact, not lost (Hornung and Reich 2006, 2007; Hornung et al. 2007).

In addition to classical works and material, new evidence has been gathered from the Obernkirchen Sandstone, beginning with the discovery of sauropod tracks in 1979 (Hendricks 1981; Fischer 1998) and culminating in continuing excavations at several localities, immensely increasing the amount of data (A. Richter et al. 2007; U. Richter et al. 2007; Richter et al. 2009; Böhme et al. 2009; van der Lubbe et al. 2009).

The objective of this paper is to comprehensively survey of the known localities of vertebrate tracks in the Obernkirchen Sandstone and to provide an up-to-date account of the stratigraphical and palaeoenvironmental data of this remarkable formation. This should serve as easy access to older locality descriptions and as a basis for further investigation of ichnological issues in this formation. The identification of these occurrences as a megatracksite in the Obernkirchen Sandstone (as proposed by Diedrich 2004) is also discussed.

\section{Abbreviations}

Institutional abbreviations BGR Bundesanstalt für Geowissenschaften und Rohstoffe, Hannover, Germany; GPMH Geologisch-Paläontologisches Museum, Universität Hamburg, Germany; GZG Geowissenschaftliches Zentrum, Georg-August-Universität Göttingen, Germany; NLMH Niedersächsisches Landesmuseum, Hannover, Germany.

Palaeogeographical and stratigraphical abbreviations DP: 'Dachplatte', hf: Hauptflöz (main coal seam), LSB: Lower Saxony Basin (Niedersächsisches Becken), OHS: Oberer Hauptsandstein (Obernkirchen Sandstone sensu stricto), UHS: Unterer Hauptsandstein.

General abbreviations H: Hochwert (northing, GaussKrüger coordinate system), R: Rechtswert (easting, GaussKrüger coordinate system).

\section{Geology and environment of the Bückeberg formation}

Exposure and stratigraphy

The Bückeberg Formation is buried beneath younger deposits across wide areas of Lower Saxony but is exposed in local uplifts, for example the mountainous areas of the Bückeberge, the Deister, the Rehburg Mountains, the southeastern Süntel, the Osterwald, and the Hils mountains (Fig. 2). South and west of the Weser Valley, it has been completely eroded. The Obernkirchen Sandstone forms a thin interval within the Obernkirchen Member, the lower member of the Bückeberg Formation, stretching in a SW to NE striking belt between the River Weser in the west and Hannover in the east. In most areas where outcrops of Obernkirchen Sandstone are revealed it was quarried, especially for high-quality building stones. Additionally, thin coal seams are intercalated with the sandstones and have been mined in shallow subsurface mines since the 13th century AD until the 1960s (Falke 1944; Graupner 1980). However, following the decline of both industries, mining has been completely abandoned and quarrying substantially reduced, leading to a decrease in accessible outcrops.

The Bückeberg Formation (Casey et al. 1975, traditionally referred to as the 'German Wealden', Hoffmann 1830, Fig. 3) comprises the middle Berriasian through early Valanginian sedimentary infill of the Lower Saxony 


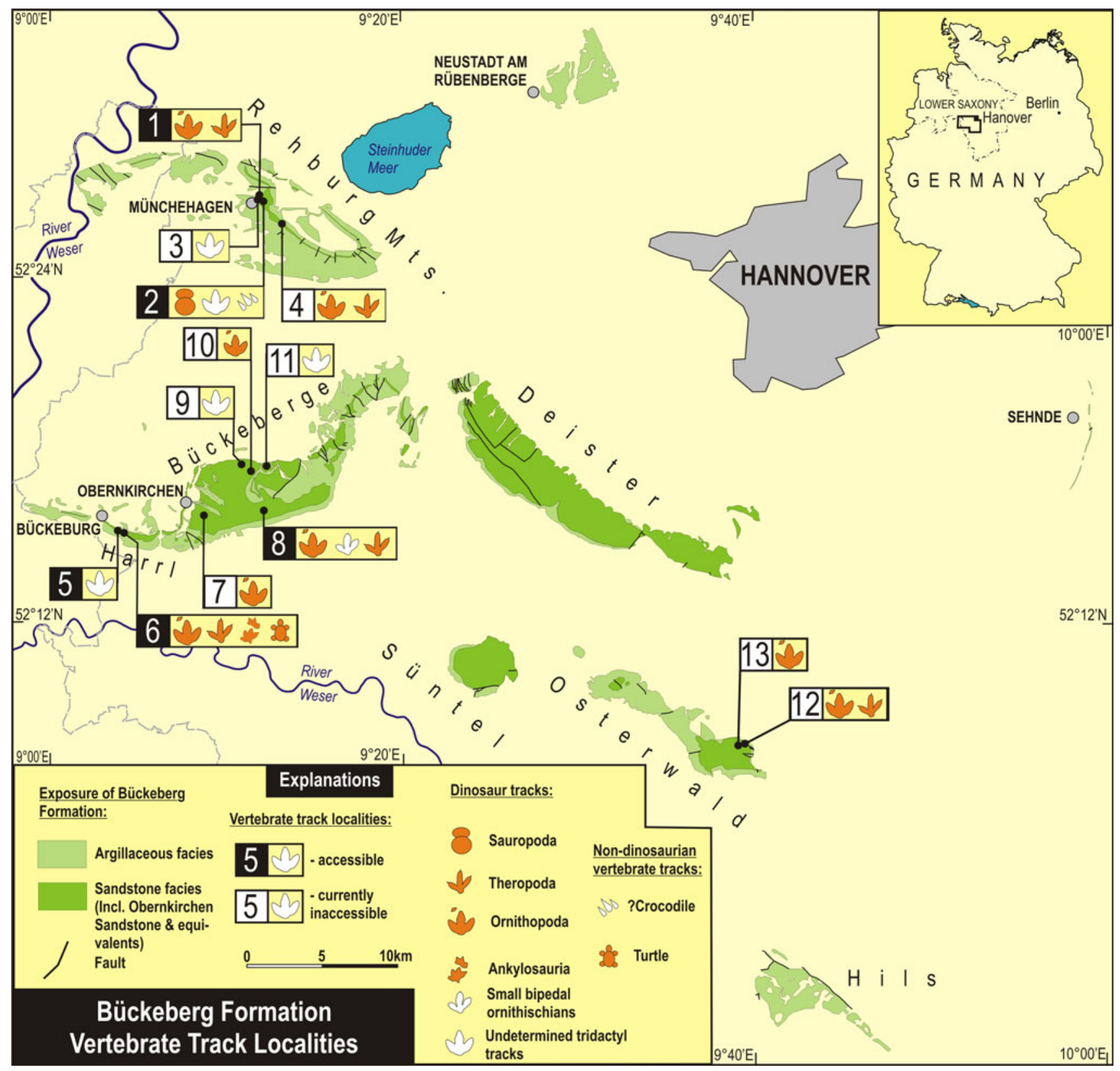

Fig. 2 Distribution of vertebrate tracksites in the Bückeberg Formation. Numbers refer to the locality numbers in the text

Basin (LSB, Fig. 4). It is underlain by evaporitic marlstones of the Tithonian through lower Berriasian Münder Formation and overlain by Valanginian marine deposits (Kemper 1973; Strauss et al. 1993; Mutterlose 1997a, 2000). The predominantly limnic nature of the Bückeberg Formation hampers exact correlation with the marine Berriasian outside the basin (Mutterlose 1997a). Internal correlation is provided by ostracod biostratigraphy (Wolburg 1949, 1959; Elstner and Mutterlose 1996). Older lithostratigraphical schemes use a subdivision into six units (W[ealden]1 to W6, Wolburg 1949). Current schemes (Elstner and Mutterlose 1996; Mutterlose 1997a, 2000) use subdivision into a basal Obernkirchen Member (corresponding to the W1 to W4) and the overlying Osterwald Member (W5 to W6).

The Obernkirchen Member can be subdivided into a finegrained argillaceous basin facies and a marginal, sandy facies. The fine-grained basinal facies reaches a thickness of up to $700 \mathrm{~m}$ in the basin centre. It consists of siltstones, mudstones, and black shales. In the entire succession, thin carbonate layers are occasionally interbedded, mostly composed of mollusc coquinas (Neomiodon spp. and gastropods).

The marginal facies attains a thickness of up to $200 \mathrm{~m}$ along the southeastern basin margin, and accumulates 
Fig. 3 Stratigraphy, lithofacies, and environment of the basal Early Cretaceous in NW Germany. Ostracods: C. $=$ Cypridea, M. = Macrodentina, $P .=$ Pachycytheridea . After Kemper 1973; Strauss et al. 1993; Elstner and Mutterlose 1996; Gramann et al. 1997; Mutterlose 1997a, 2000; and others, modified

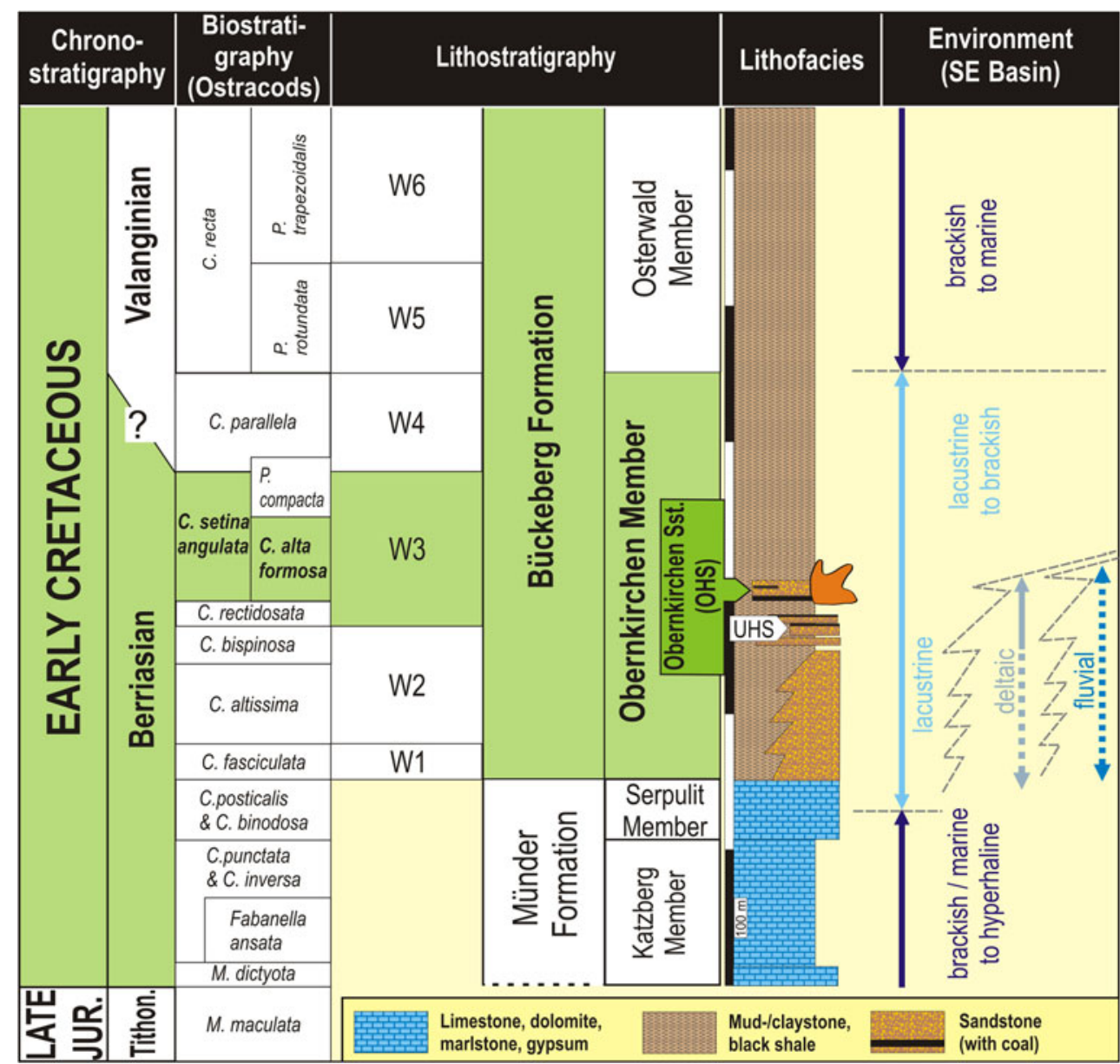

Thin intercalated coal seams are common throughout the Obernkirchen Sandstone and its equivalents, including the Osterwald and Hils mountains (Falke 1944; Graupner 1980; Pelzer et al. 1992). They were used in early attempts at detailed intraformational lithostratigraphy of the sandstone succession across the Rehburg Mountains, Bückeberge, and Harrl hill (Grabbe 1883; Grupe 1933; Falke 1944; Graupner 1980). Up to five superimposed, $\mathrm{cm}$ to $\mathrm{dm}$-thick coal seams have been reported intercalated with the sandstones (Figs. 5, 6). However, lateral correlation of these coal seams spanning wider distances is questionable. Only the most important Hauptflöz (main seam, hf in Figs. 5, 6) can be traced below the Obernkirchen Sandstone across the Bückeberge, where a prominent coal layer, up to $80 \mathrm{~cm}$ thick, is embedded at the base of the sandstone complex. A similar situation is present at the Rehburg Mountains, where the thickest seam is located at the base of the sandstone succession, suggesting a potential correlation. The coal seams in the outcrops at Harrl hill are intercalated within a different lithofacies succession and previous correlation attempts, for example that by Grupe (1933), are still very weakly supported.

In many outcrops and subsurface logs, the Hauptflöz is separated from the overlying Obernkirchen Sandstone by a 
Fig. 4 Berriasian palaeogeography (after Schott et al. 1967, 1969; Kemper 1973, Pelzer 1998, modified) and vertebrate tracksite occurrences in the Lower Saxony Basin

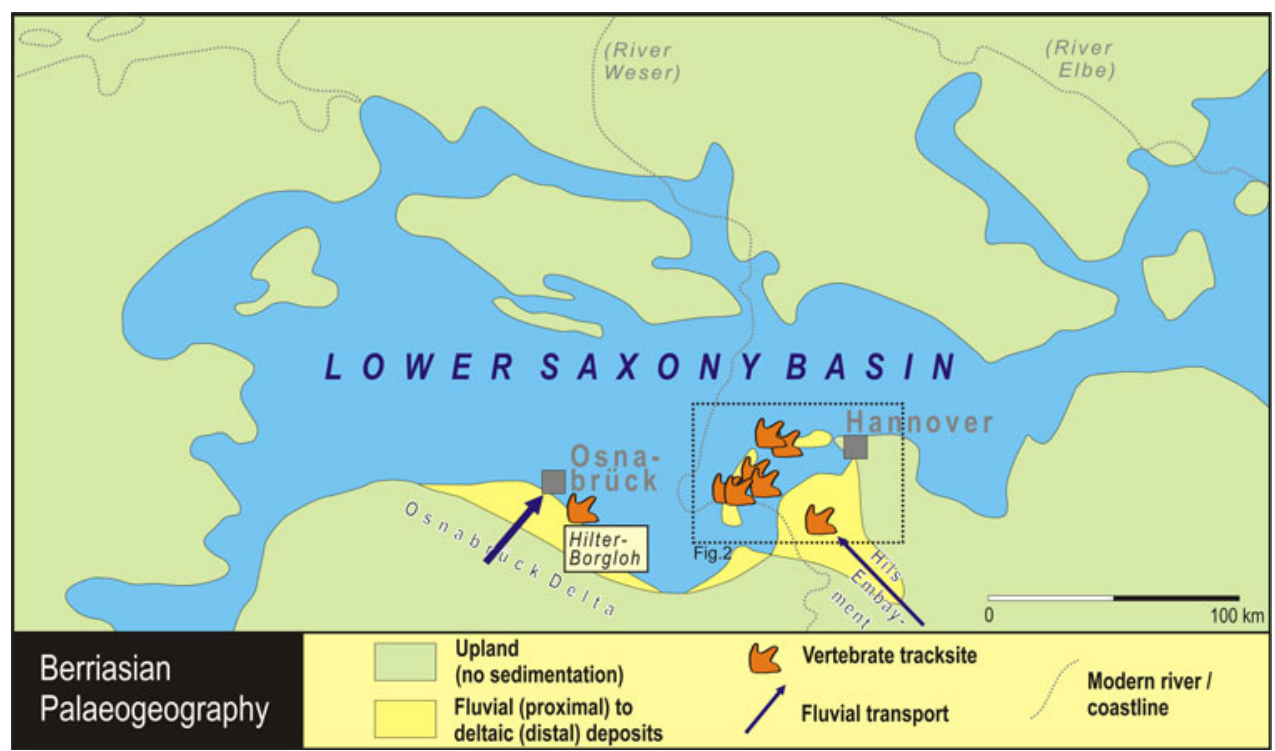

0.5-1.5 m fine-grained interval, the 'Dachplatte' (DP, Figs. 5, 6b). This unit is locally very fossiliferous and has yielded especially rich plant and vertebrate remains (Grabbe 1883; Dames 1884a).

The distal sandy complex correlates biostratigraphically with the Cypridea alta formosa ostracod subzone (upper Berriasian, Elstner and Mutterlose 1996) and is nested well within the lower part of W3. Diedrich (2004) assigned the upper part of the Obernkirchen Sandstone at the Obernkirchener Sandsteine GmbH quarry (locality 8) to the W4 (C. jonesi/C. parallela ostracod biozone). However, this is not in agreement with other stratigraphical schemes (Jordan 1979), and because Diedrich (2004) did not provide any data or rationales for his correlation, it is not followed herein.

South of Hannover, the sandy facies increasingly dominates and conglomerate layers are rarely intercalated (Struckmann 1880a). Because of the lack of adequate lithostratigraphical and biostratigraphical marker-beds, exact correlation of the UHS and OHS with the more proximal sandy beds toward the SE is not possible.

The overlying Osterwald Member shows a retrogradational facies trend with a margin-ward onlap of the finegrained basin facies. A marginal, coarse-grained facies is restricted to the south-easternmost region of the Hils Embayment (Pelzer 1998).

\section{Palaeogeography}

The LSB (Fig. 4) is an adjacent subbasin of the North German Basin, which stretches across most of central northern Germany and westwards into the eastern part of The Netherlands (Schott et al. 1967, 1969). Its subsidence began during the Late Jurassic and continued into the early
Late Cretaceous, when it was terminated by basin inversion (Betz et al. 1987; Bachmann and Grosse 1989).

Communication of the LSB with the main North German Basin was maintained only through narrow gateways in the SW, W, and E (Schott et al. 1967, 1969). The basin fill facies was governed primarily by eustatic sea level fluctuations and/or local tectonic opening of gateways which connected or unconnected the LSB from the Tethys and Boreal Ocean (Kemper 1973, 1992; Elstner and Mutterlose 1996; Mutterlose and Bornemann 2000). Following disconnection from marine influx, after deposition of the marine-brackish to hyperhaline upper Münder Formation (early Berriasian, Arp and Mennerich 2008), short-time ingressions occurred from the W and SW (Holland) during the latest W2 and throughout W3 (Elstner and Mutterlose 1996; Mutterlose and Bornemann 2000; Berner et al. 2010; Berner 2011) resulting in a W-E-decreasing salinity gradient across the LSB. The eastern part remained oligohaline until the latest Berriasian or earliest Valanginian (W4) when marine microfaunas occur temporarily in the eastern part of the basin also (Martin 1961a; Mutterlose and Bornemann 2000). On a secondary scale, the LSB facies and palaeogeography were controlled by autocyclical processes, including local tectonics (including halotectonics and subrosion of Permian evaporites), differential subsidence, and intra-basinal, climatically controlled base-level fluctuations during phases of disconnection from the global sea-level (Mutterlose and Bornemann 2000). These factors dominated the sedimentation within the LSB from the Jurassic/Cretaceous boundary well through the latest Berriasian.

After local highstand and marine flooding of most of the incipient LSB during the Late Jurassic (Gramann et al. 1997; Kästner et al. 2008), a major fall in sea level and 


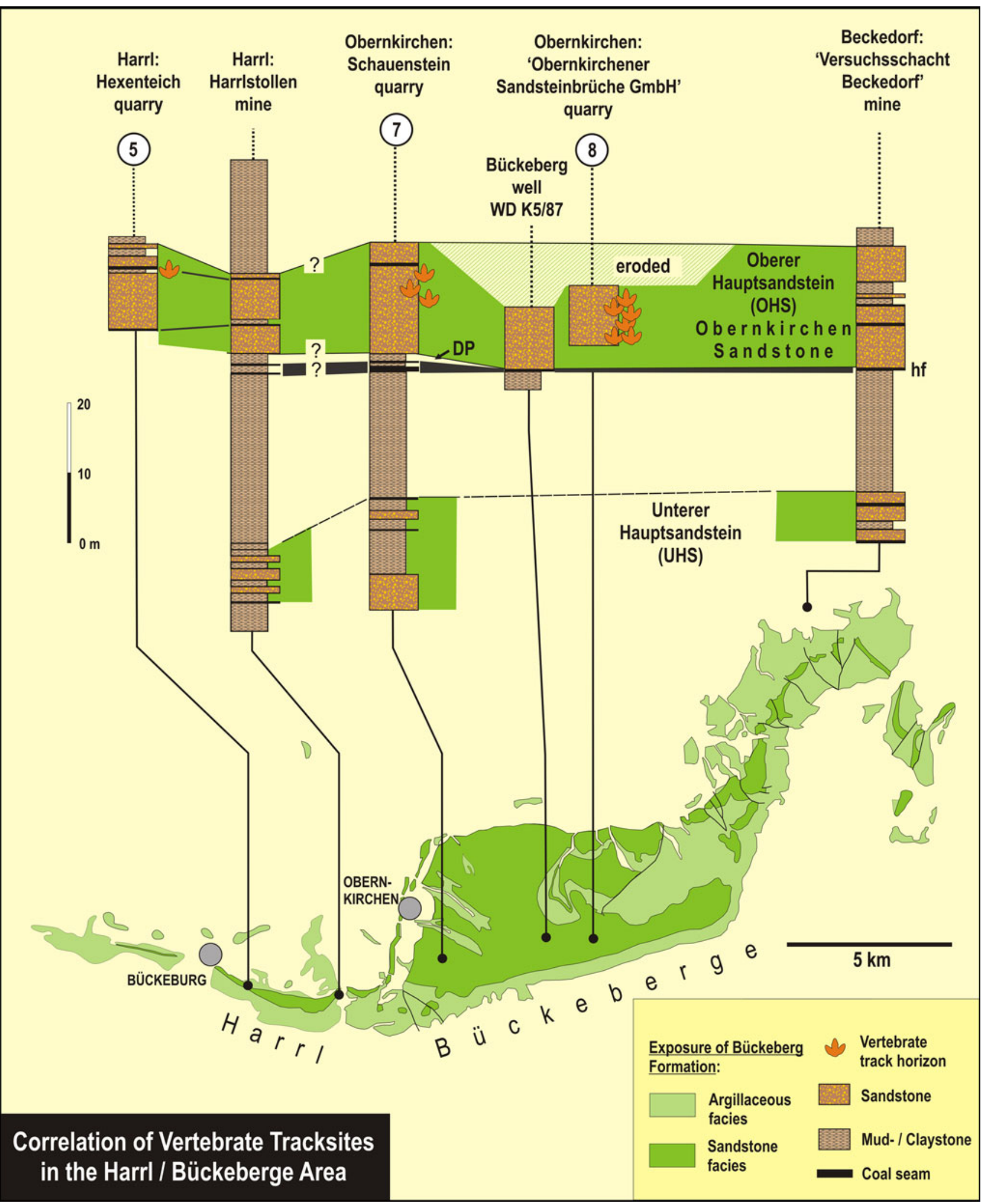

Fig. 5 Lithostratigraphical correlation of outcrops in the Bückeberge and Harrl areas. Note the weakly supported correlation of the trackbearing beds of Harrl hill with those of the central Bückeberge.
Encircled numbers refer to locality numbers in text. Lithological data after Dietrich 1927, Grupe 1930, Pelzer 1998, and our own observations 
early basin subsidence led to isolated, shrinking perimarine water bodies in the developing LSB during deposition of the Tithonian through earliest Berriasian Münder Formation. These beds were regarded as the equivalent of the English Purbeck beds in the 19th and early 20th century literature (Struckmann 1880a). The lower part of the Münder Formation is dominated by marlstones, locally evaporitic (Katzberg Member) and contains low-diversity faunal assemblages with dominant local biostromes of the sedentary polychaete Serpula coacervata (Blumenbach, 1803) and increasing influx of freshwater in the upper part of the Münder Formation (Serpulite Member, Borberg Member; Arp and Mennerich 2008).

During early to mid-Berriasian times, precipitation increased and a lacustrine water body began to spread in the basin centre, fed by river systems draining the basin margins and uplands (Pelzer 1987; Pelzer and Wilde 1987; Pelzer et al. 1992; Wilde et al. 1995). The river systems reached substantial dimensions with meandering beds and extensive belts of well-vegetated floodplain deposits, backswamps, and associated lakes, as documented by related deposits in the southeast of the LSB (Pelzer 1984; Pelzer et al. 1992). The relatively undisturbed succession of fine-grained deposits in the basin centre (Kemper 1973) suggests that a central lake was continuously present throughout the Berriasian. However, transgressive-regressive patterns of this lake are not well known. Transgressive sequences can be traced in parts of the succession and an overall expansion of the lake is assumed for most of its existence. The fluvial facies is exposed in the Hils and Osterwald mountains (Pelzer 1984, 1998; Pelzer et al. 1992; Riegel et al. 1986).

It is of importance to note that the vertebrate trackbearing deposits of the Obernkirchen Sandstone are all located within this limnic depositional system, contrary to a few publications (Diedrich 2004; Lockley et al. 2004) which regard this as marginal-marine in origin.

In the Osterwald mountains, fluvial large-scale crossstratified, up to $12 \mathrm{~m}$ thick (channel-fill?) sandstones (Obernkirchen Member) are abruptly overlain by a thin conglomerate, interpreted as a transgressional beach deposit, passing upwards into perideltaic brackish-marine sediments (Osterwald Member; Waldeck 1969; Pelzer 1998). Palynological data suggest that the marginal river systems were still active in Valanginian times (Pelzer 1984) when the basin centre was reoccupied by marine waters because of eustatic sea level rise.

At least one fluvial system apparently occupied the axis of the Hils Embayment. The system terminated downstream in the Bückeburg-Bad Rehburg-Hannover area, where an extensive, shallow-water deltaic system (Kauenhowen 1927; Graupner 1980; Pelzer et al. 1992; Pelzer 1998) became established during the mid- to late
Berriasian. This system is represented by the distal reaches of the Hannover sedimentary wedge. The sandstones and intercalated fine-grained sediments preserve a diverse assemblage of sedimentary facies, representing several subenvironments. Pelzer (1998) proposed a barrier/backbarrier setting for the Obernkirchen Sandstone with severe storm events as an important landward transport mechanism for reworked and matured terrigenous sand in this microtidal environment. Current work suggests that the Obernkirchen Sandstone encompasses several facies assemblages, including back-barrier storm deposits in the Rehburg Mountains and a landward deltaic succession in the southern and western Bückeberge (see the discussion below).

On the landward side of the lagoons, swamps existed, passing into peat-bogs and vegetated areas on emergent and stabilised interchannel and interlagoonal islands (Wilde et al. 1995; Pelzer et al. 1992; Pelzer 1998).

The dinosaurs apparently passed across the shore-face, back-barrier, deltaic and alluvial flats, and through shallow lagoonal waters. The preservation of multiple, vertically stacked barrier and lagoonal deposit successions within the Obernkirchen Sandstone and abundant interbedded palaeosols and authochthonous coal seams indicate a long-term net aggrading sedimentary regime under transgressive conditions, favouring also the preservation of vertebrate tracks. However, erosional discontinuities on a local scale have been reported in some outcrops (Fischer 1998; Pelzer 1998).

\section{Palaeoecology}

The only well-studied microfaunal group are the ostracodes, which provide the biostratigraphic framework of the nonmarine Berriasian (Martin 1940, 1958, 1961b; Wolburg 1949, 1959, 1962, 1971; Schudack and Schudack 2009).

The invertebrate macrofauna in the lagoonal deposits is dominated by mollusc assemblages (predominantly Unionidae, Neomiodontidae and various gastropods; Dunker 1846, 1849; Struckmann 1880a; Huckriede 1967). Modern detailed taxonomic and diversity studies of these groups are still lacking. Abundant endobenthic invertebrate trace fossils (Schwennicke 1998) indicate normally oxygenated conditions for the lagoonal water bodies in the Münchehagen area.

Aquatic vertebrates are represented by elasmobranchians (hybodontoid, petalodontid, and neoselachian sharks) and several species of actinopterygian fishes, including members of Semionotiformes, Pycnodontiformes, Amiiformes, and Pholidophoriformes (Dunker 1846; Struckmann 1880a; Branco 1887; Martin and Weiler 1954; Schultze 1970; López-Arbarello et al. 2007, Nyhuis and Herbig 2009). A maximum of fish diversity is known from 


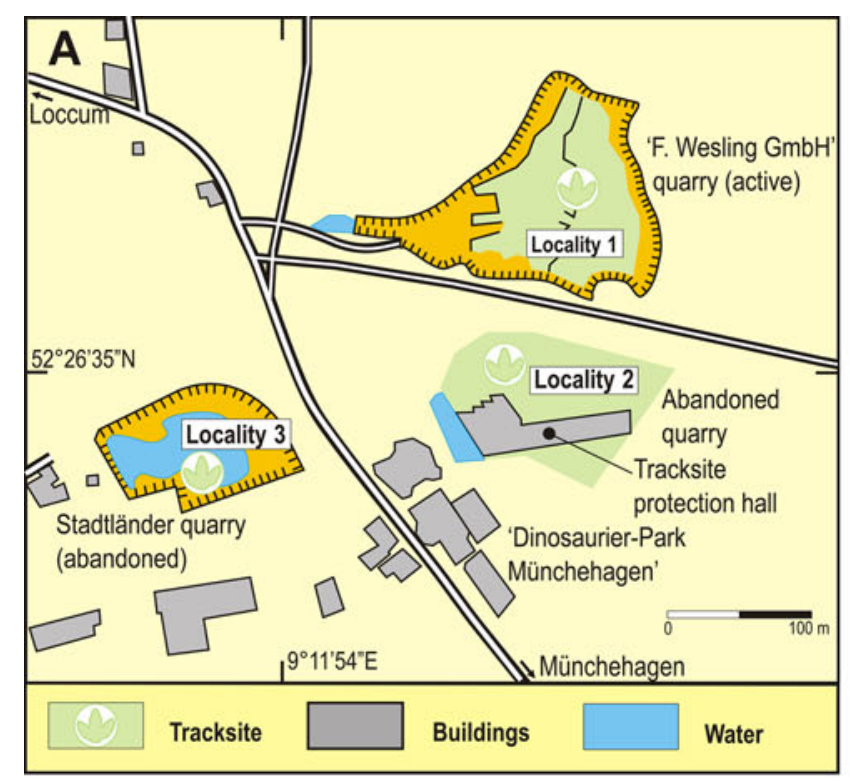

B

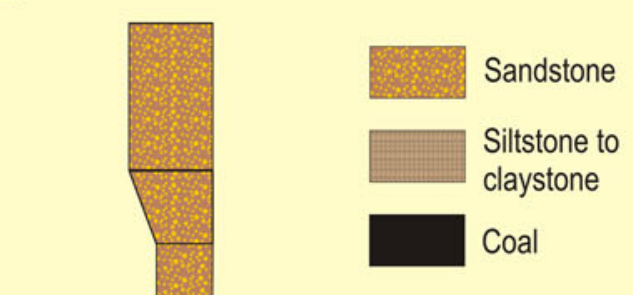

Disc. Discontinuity surface
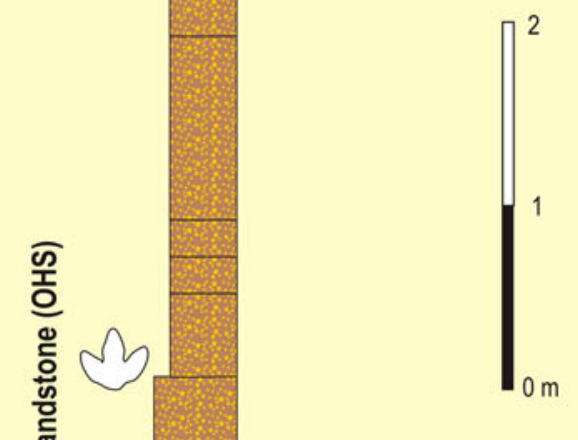
4 Fig. 6 a Geographical overview of the tracksites near Münchehagen (localities 1-3, Rehburg Mts.); b Simplified lithological logs of localities 1-3, showing lateral correlation and track horizons. Lithological data after Wilde et al. 1995, Fischer 1998, Pelzer 1998, and our own observations. Track symbols are eplained in Fig. 2

concentrated, tempestitic bone-beds, deposited in the Osterwald Member in the western, deeper basin (Nyhuis and Herbig 2009). In the southeastern, sandy facies of the Obernkirchen Member, the known fish fauna is so far confined to hybodontoid sharks (fin spines, teeth, and egg capsules) and semionotids (including some splendid specimens of "Lepidotes" mantelli Agassiz, 1833; see Branco 1887; López-Arbarello et al. 2007).

Plesiosaurs also inhabited the LSB, including Brancasaurus brancai Wegner, 1914 known from a rather complete skeleton from the Osterwald Member of Gronau/ Westphalia (Wegner 1914). Isolated plesiosaur skeletal elements are furthermore known from various localities and facies (Koken 1887, 1896). Semiaquatic vertebrates are mostly represented by the very abundant and diverse turtles (at least seven species of basal cryptodirans; Grabbe 1884; Peitz 1998; Karl et al. 2007a, b) and by the common mesoeucrocodylian crocodile genera Goniopholis Owen, 1842 and Pholidosaurus von Meyer, 1841 (von Meyer in Dunker 1846; Koken 1883, 1886, 1887, 1896; Jaffé 1912; Edinger 1938; Salisbury et al. 1999).

The fauna of fluvial and alluvial environments is less well-known, although mollusc shell-beds and bone-bed layers are present (Pelzer 1984, 1998). Fine-grained overbank deposits preserved a few terrestrial arthropods, for example insects (Coleoptera) and possibly arachnids (Struckmann 1880a; Pelzer 1984; Pelzer et al. 1992).

The terrestrial vertebrate fauna was mainly composed of dinosaurs, but only the small ornithischian Stenopelix valdensis von Meyer, 1857 is represented by a largely complete, articulated postcranium (Schmidt 1969; Sues and Galton 1982; Butler and Sullivan 2009). Besides the track record, Ornithopoda, Ankylosauria, Theropoda, and Sauropoda have also been identified from isolated bone fragments (Dames 1884a, b; Koken 1887; Struckmann 1894; Sachs 1997; Windolf 1998; Hornung unpublished data).

A single specimen of pterosaur, the holotype of Ctenochasma roemeri von Meyer, 1851, was found in the Deister mountains. Although considered to be Late Jurassic in age, for example by Wellnhofer (1991), the information provided by von Meyer (1851) supports an origin from the Serpulite Member of the Münder Formation and therefore a basal Berriasian age, as suggested by Bennett (2007). So far no pterosaurs are known from the limnic mid- to late Berriasian deposits.

The palaeoflora is known from leaf impressions in finegrained sediments, stem-impressions in sandy sediments, macro- and microremains from lignites, and root-traces, including strongly rooted palaeosol horizons, and, rarely, amber. Palynomorphs and macroremains indicate various floral communities, including pioneer, swamp and floodplain vegetation, and forested areas (Pelzer 1984, 1998; Pelzer et al. 1992). Aquatic plants are represented by dinoflagellates and charophytes (Schudack 1996; Pelzer 1998). Major terrestrial plant taxa include Coniferae, Equisetales, Ginkgophyta, Cycadophyta, Pteridophyta, Bryophyta, and Fungi (Lipps 1923; Mägdefrau and Rudolf 1969; Hiltermann 1949; Pelzer 1984, 1998; Riegel and Wilde 1984; Wilde and Heunisch 1990; Wilde 1991; Wilde et al. 1995). Various morphotypes of root-traces, rhizomes of Equisetales and log impressions are very common plant remains associated with the track-bearing sandy facies (Pelzer 1998).

Facies and lithology of vertebrate track-bearing horizons

The vast majority of vertebrate (mostly dinosaur) tracks from the Obernkirchen Member are from the limnic deltaic-estuarine deposits, more precisely from the OHS deltaic-estuarine sandstones. However, some tracks have also been described from the fluvial and alluvial facies in the Osterwald mountains (Naumann 1927).

Dinosaur track horizons in the deltaic-estuarine environment commonly occur in $\mathrm{mm}$ - to dm-thick sandstone beds interlayered with $\mathrm{mm}$ - to $\mathrm{cm}$-thick sandy or silty claystones and mudstones. The sandstones are often massive or internally ripple to large-scale cross-stratified, horizontally laminated or flaser-bedded with oscillation or unidirectional ripple-marks at the top. Thick-bedded sandstone layers are often composed of amalgamated sublayers.

Lithofacies data indicate that vertebrate tracks were left in various subenvironments of the deltaic-estuarine system. In the Münchehagen area (localities 1-3, Fig. 7a), the tracks were left on top of dm-thick sandstone beds, which have a slightly erosive base and a predominantly massive or diffusely horizontally stratified texture. The uppermost centimetres are wave-reworked and have well-preserved oscillation-ripple cross-lamination and intensive invertebrate bioturbation, overlain by $1-10 \mathrm{~cm}$ thick drapes of siltstones to mudstones. The thick bedding and massive texture indicates rapid deposition from voluminous highly concentrated density flows with limited turbulence at the flow base. The best preserved dinosaur tracks and ripplemarks occur at the contact between the top of sandstone beds and the base of relatively thick $(2-5 \mathrm{~cm})$ siltstones to claystones. These boundaries contain sub-millimetric, smooth, carbonaceous films covering the surface of the oscillation ripple-marked sandstones. The films are 

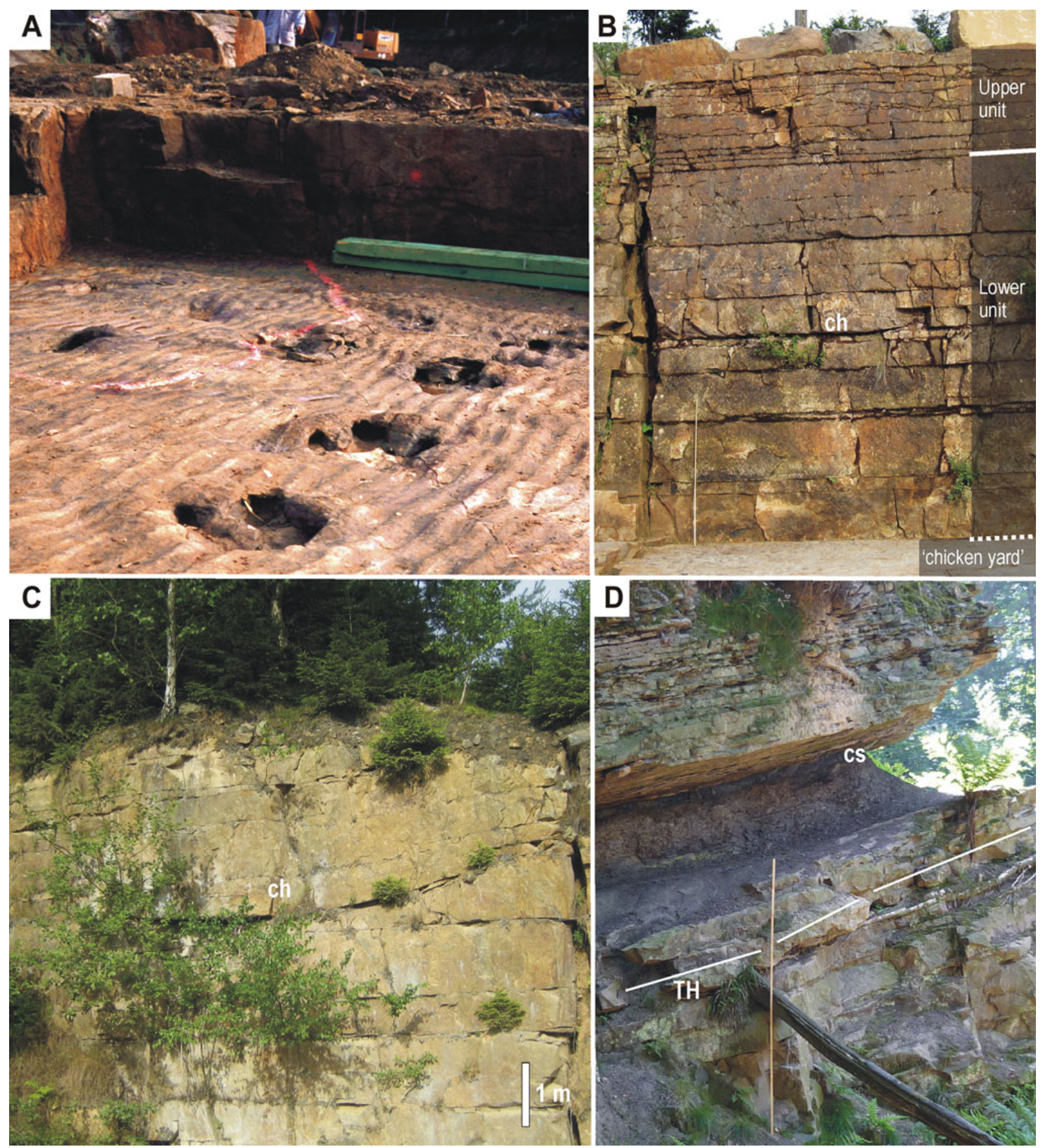

Fig. 7 Typical dinosaur track-bearing lithofacies of the Obernkirchen Sandstone. a Thick-bedded, massive sandstone beds with oscillation ripple-marks at the top, intercalated by $\mathrm{mm}$ to $\mathrm{cm}$-thick sandy siltstone to claystone layers. In the foreground a large ornithopod track. The sandstone beds in the background have a thickness of 70-100 cm. Münchehagen/F. Wesling GmbH quarry (ch) (locality 1), 2005; b Medium-bedded, partly amalgamated and channellised ( $\mathrm{ch}$ ) finegrained sandstone beds, intercalated by $\mathrm{mm}$ to $\mathrm{cm}$-thick siltstone to claystone layers. Note the overall thinning-upward trend. The surface at the base of the image is the so-called "chicken yard" track horizon
(Fig. 15). "Upper" and "lower unit" refer to a lithological subdivision, which can be traced between adjacent quarries at a local scale (see locality description for further details). Scale: $2 \mathrm{~m}$. Obernkirchen/Obernkirchener Sandsteinbrüche quarry (locality 8), 2009; c Channellised (ch), medium to thick-bedded sandstone, "lower unit", Obernkirchen/Obernkirchener Sandsteinbrüche quarry (locality 8), 2009; d Thin to medium-bedded, scoured, massive sandstone beds, overlain by a soft succession of sandy siltstone to mudstone and capped by a thin coal-seam $(c s)$. Pelzer (1998) tentatively identified a track horizon $(T H)$ in this succession. Bückeburg/ abandoned quarry at the W' side of Harrl hill (locality 5), 2009 


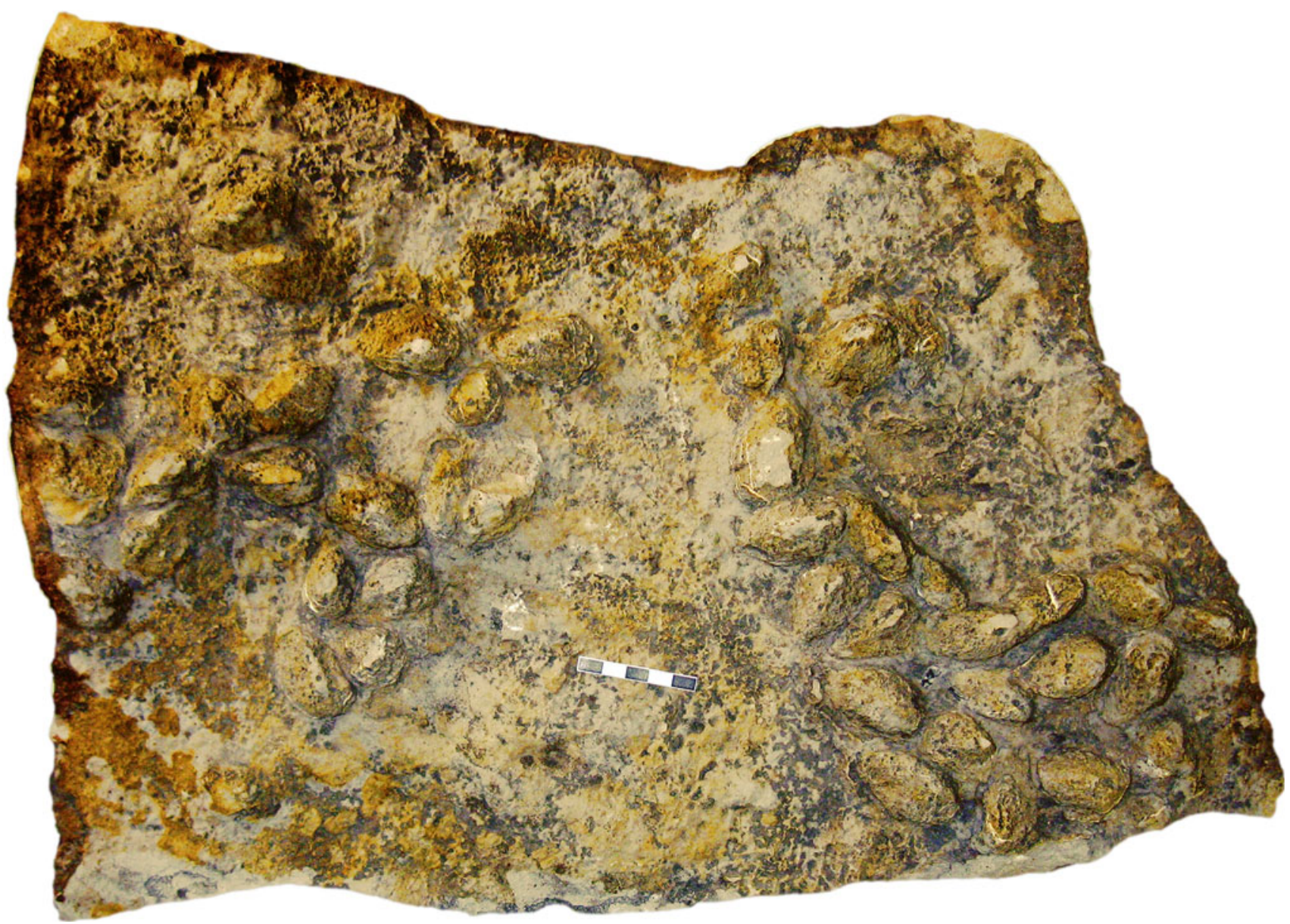

Fig. 8 Lockeia isp. (NLMH 105.745A), resting traces of unionid bivalve colony at the underside of a dm-thick, massive sandstone layer indicating sudden burial under rapidly deposited sediment after prolonged period of undisturbed growth. Bückeberg Formation, Obernkirchen Member, Münchehagen/F. Wesling GmbH quarry (locality 1). Scale bar $5 \mathrm{~cm}$ probably the remnants of microbial mats (Eriksson et al. 2007) which grew on the freshly deposited sand grounds before being covered by the subaqueous deposition of pelitic sediments. They probably helped to prediagenetically stabilize ichnia and sedimentary structures by providing increased cohesion. Stacked and partly amalgamated sandstone layers are in places separated by wavy-irregular, often laterally discontinuous boundary surfaces, often covered by very thin clay vails. Seen from above, these surfaces have a reticulated pattern of mm-wide grooves separated by sharp ridges. Similar structures have been described to be formed by desiccated microbial mats in ephemeral pools on supratidal sandbars in extant environments (Bose and Chafetz 2009). Together with extremely rare desiccation cracks these structures are indicative of temporary emersion of the sandy deposits.

These deposits are interpreted to be associated with storm-reworked barrier sands, splayed into back-barrier lagoons (Pelzer 1998). Such an event-based sedimentation is concordant with the presence of cluster-like colonies of fully grown, gregarious, infaunal unionoid bivalves (Fig. 8, see also Schwennicke 1998). Growth to several centimetres in shell-length required years to decades before the population was extinguished or forced to relocate by rapid burial. The $10^{1}$ to $10^{2} \mathrm{yr}$ frequency of high-energy deposition supports an association with severe storm events.

The lacustrine setting, in concordance with the absence of clear indicators of regular rhythmic tidal currents (e.g. herring-bone cross-stratification) and rarity of signs of sustained unidirectional currents, precludes astronomical tides as sediment-transport mechanism. However, storminduced tides, piling water in shallow littoral regions as the Hils Embayment may explain temporal inundation of intertidal to supratidal areas after the deposition of stormmobilized sediments. Subsequent desiccation of such isolated supratidal water bodies can explain the occurrence of features such as the reticulated microbial mat structures (compare Bose and Chafetz 2009).

The relative abundance of interspersed channel- and scour-fill sandstones, often containing root-traces and 
separated by knobby-irregular, clay-draped boundary surfaces at Obernkirchen (Bückeberge, locality 8, Fig. 7b, c) indicate a facies setting rather different from that at the Rehburg Mountains. The knobby surfaces are always associated to rooted horizons. These surfaces, which were first described as stacked palaeosols by Grupe (1931), are very similar to structures formed by desiccated microbial mats on vegetated, supratidal sandbars (Bose and Chafetz 2009). They indicate subaerial exposure which lasted long enough to enable the growth of a rather dense vegetation cover. Channel-fill deposits occasionally have large-scale trough cross-stratification and coarsergrained basal lags. Together with the diffusely horizontally stratified or structureless, laterally extensive sandstone beds, these observations suggest a shallow-water deltaic mouthbar complex, in which the tops of mouthbars became emersed and vegetated following the drop of the local water-table after periods of very strong, probably seasonal discharge. Dinosaur tracks occur on the top of channel complexes and on rootedknobby surfaced and plain sandstone layers. The quality of track preservation varies substantially, but is generally inferior to that in the Münchehagen area. Track-covered surfaces were probably at least partially subaerially exposed and degraded because of the lack of a protective mud layer, vegetation growth, and surface modification by desiccating microbial mats (compare Marty et al. 2009).

At Harrl hill (localities 5 and 6, Fig. 7d), at least one track horizon is situated near the top of a thinning-upward, scoured sandstone succession, passing upwards into several $\mathrm{dm}$ of ripple cross-laminated siltstones to mudstones and capped by a coal seam (Pelzer 1998). The facies assemblage suggests an aggrading mouthbar under transgressive conditions, overlain by proximal shallow-lagoon sediments, when the base-level rise forced retrogradation of the system or the mouthbar became inactive by avulsion. Finally, a peat-bog swamp became established under highstand conditions. The dinosaur tracks were left on top of the shallowly submerged mouthbar.

The dinosaur tracks from fluvial deposits at the Osterwald mountains (localities 12 and 13) are preserved at the base of medium-bedded, partly current-ripple cross-laminated sandstones, overlying partly coal-bearing clay- and mudstones rich in plant macrofossils (Naumann 1927). Crevasse-splay deposited sand probably rapidly covered the fine-grained overbank mud in which the tracks were made.

Tracks are commonly preserved as hyporeliefs on the lower surface of sandstone beds. The fine-grained intervals are poorly inundated and the trackway impressions (positive epireliefs) are often destroyed during exposure if not preserved by artificial casting (Grabbe 1881; Hamm 1938; Lehmann 1978). However, this type of preservation may be over-represented in historical collections as it was logistically easier to collect blocks with isolated hypichnia than to remove the track-bearing layer. Thin mudstone intercalations support the preservation of epireliefs on an underlying sandstone surface either by penetration of the mud layer by the foot or by undertracks. Thinly bedded sandstones with intercalating mudstone laminae also favour the preservation of undertracks.

\section{Vertebrate track inventory of the Bückeberg Formation (Table 1)}

As this work is not intended as a thorough ichnotaxonomical revision of the vertebrate ichnofauna, which will be given elsewhere, only a short overview and

Table 1 Distribution, taxonomy, and abundance of dinosaur tracks across the localities discussed herein

\begin{tabular}{|c|c|c|c|c|c|c|c|c|c|c|c|c|c|}
\hline \multirow{2}{*}{$\begin{array}{l}\text { Region } \\
\text { Locality }\end{array}$} & \multicolumn{4}{|c|}{ Rehburg Mountains } & \multicolumn{2}{|c|}{ Harrl hill } & \multicolumn{5}{|c|}{ Bückeberge } & \multicolumn{2}{|c|}{ Osterwald Mts. } \\
\hline & 1 & 2 & 3 & 4 & 5 & 6 & 7 & 8 & 9 & 10 & 11 & 12 & 13 \\
\hline SAUROPODA & & + & & & & & & & & & & & \\
\hline \multicolumn{14}{|l|}{ THEROPODA } \\
\hline 'Bueckeburgichnus' maximus & & & & + & & + & & + & & & & & \\
\hline 'Megalosauripus' isp. & & & + & + & & & & + & & & & & \\
\hline Didactyle morphotype & & & & & & & & + & & & & & \\
\hline ORNITHOPODA & $?$ & & ++ & ++ & $?$ & ++ & ++ & ++ & & + & & + & + \\
\hline \multicolumn{14}{|l|}{ ANKYLOSAURIA } \\
\hline Metatetrapous valdensis & & & & & & + & & & & & & & \\
\hline UNID. TRIDACTYLE & & + & & & & & & + & + & & + & & \\
\hline \multicolumn{14}{|l|}{ DINOSAUR TRACKS } \\
\hline CHELONIA & & & & & & + & & & & & & & \\
\hline CROCODYLIA & & & & & & & & ? & & & & & \\
\hline
\end{tabular}

Abundance: $(+)$ rare to very rare, $(++)$ abundant; (?) identification uncertain 
Fig. 9 Dinosaur track morphotypes from the Obernkirchen Sandstone. a Brontopodus isp. $=($ Rotundichnus muenchehagensis Hendricks, 1981), sauropod trackway, locality 2 (from Lockley et al. 2004, modified);

b 'Bueckeburgichnus' maximus Kuhn, 1958, large theropod track, locality 6 (from Lockley 2000 , modified);

c 'Megalosauripus' isp., moderately sized theropod track, locality 8 (from Diedrich 2004, modified); d Large ornithopod pes track, the presence of a vestigial hallux in this track morphotype is questionable, locality 7 (after Dietrich 1927; Kuhn 1958, modified); e Large ornithopod trackway with manus imprint, locality 2 (from Lockley et al. 2004, modified); f Large ornithopod trackways, adult and subadult/juvenile tracks, locality 8 (from Lehmann 1978, modified); g Metatetrapous valdensis Nopcsa, 1923, ankylosaur track, locality 6 (from Ballerstedt 1922, modified). Scale bar $1 \mathrm{~m}$, note different scale in $\mathbf{a}$ and $\mathbf{b}-\mathbf{g}$

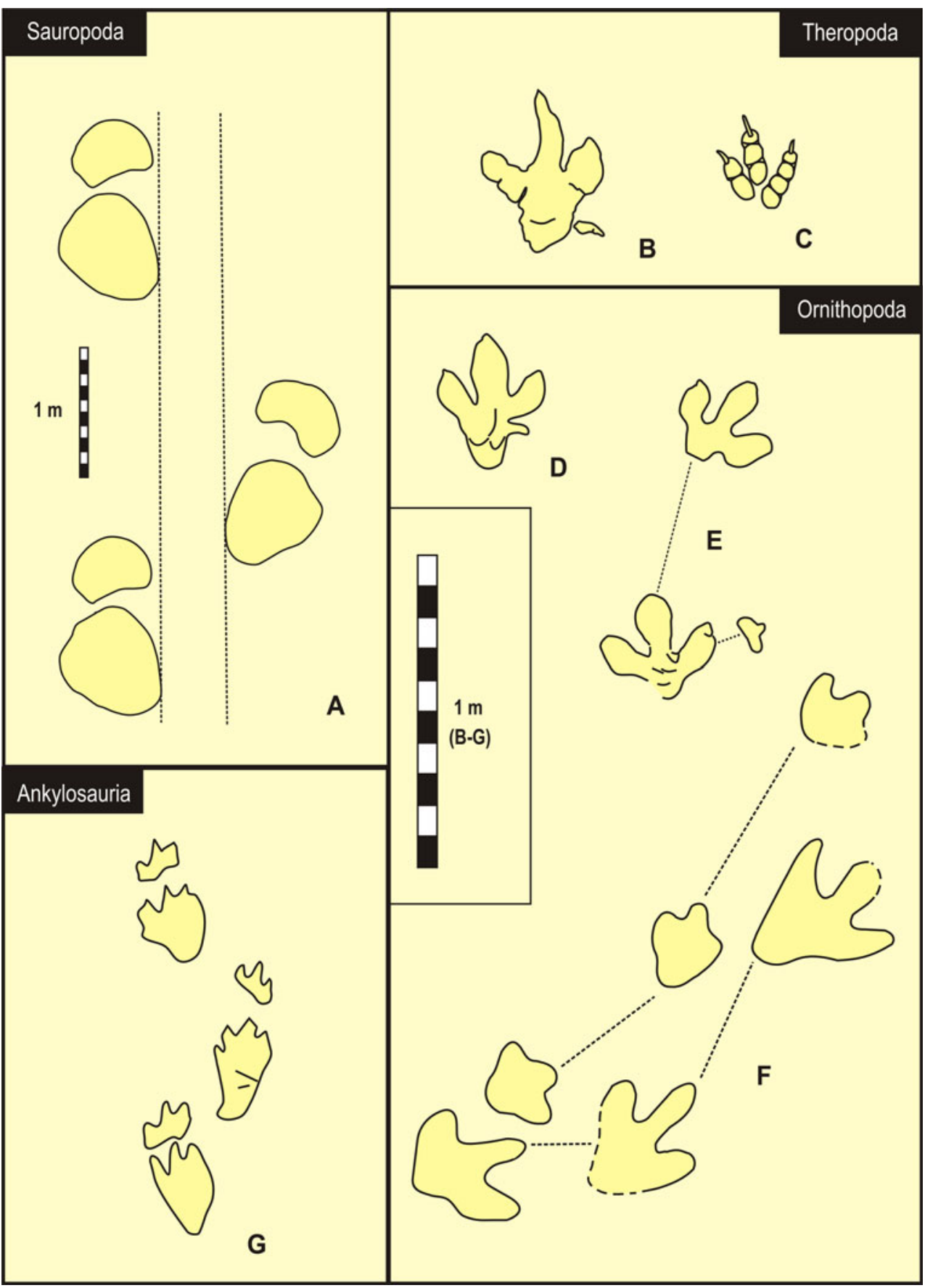

terminological framework for the locality section will be given here. Several dinosaur ichnotaxa have been formally established on the basis of material from the Bückeberg Formation; however, virtually none of these are correctly diagnosed or undisputed.

\section{Sauropoda (Fig. 9a)}

Sauropod trackways (Fig. 9a) are known only from the "Dinosaurier-Park Münchehagen" open-air museum (locality 2; Hendricks 1981; Lockley et al. 2004). A new ichnotaxon, Rotundichnus muenchehagensis Hendricks, 1981, has been established for these tracks, but this has not found wide acceptance, because the tracks do not preserve many morphological details (Lockley et al. 1994, 2004; Wright 2005). Their general morphology is similar to that of the wide-gauge ichnogenus Brontopodus Farlow, Pittman and Hawthorne, 1989. Despite confirming its status as nomen dubium, Wright (2005) proposed characters to distinguish Rotundichnus from Brontopodus and denied the referral of the Münchehagen tracks to the latter. The main differences pointed out by Wright (2005) were subcircular 
manus impressions (narrowly arc-shaped in Brontopodus) and a manus width circa two times the manus length (nearly equal in Brontopodus). However, the manus impressions are more crescent-shaped in Rotundichnus than illustrated in Wright (2005: fig. 9.5J and 9.5G respectively, compare with Lockley et al. 2004: figs. 4-5 and to Fig. 9a herein).

An occurrence of Brontopodus isp. sauropod tracks at Harrl hill as indicated by Diedrich (2004: fig. 1) is not supported by previous reports or the original material.

Theropoda (Figs. 9b, c, 16b, c, 18a, b)

Theropod tracks (Fig. 9b, c) are common in the LSB but have been misidentified as ornithopod tracks on various occasions. The first description of theropod tracks from the Obernkirchen Sandstone were given by Grabbe (1883: 20), who noted moderately sized tridactyl footprints (footlength ca $25-30 \mathrm{~cm}$ ) with an asymmetric metatarsal region and distinct claw marks. Unfortunately, he did not provide figures or a detailed locality (?Harrl hill). The first indisputable figures of theropod tracks were published by Ballerstedt (1905); these were from Harrl hill.

Theropod footprints occur in various size classes and morphotypes. One distinct morphotype is represented by large, functionally tridactyl footprints, which often preserve the small digit I on deep casts and show a broad, robust digit II (Fig. 9b). This morphotype has been named Bueckeburgichnus maximus Kuhn, 1958 (see Lockley 2000; Lockley et al. 2004). However, Thulborn (2001) reasonably argued that the ichnogenus Megalosauripus Lessertisseur, 1955 is available as a valid senior synonym of Bueckeburgichnus. We tentatively retain here the name 'Bueckeburgichnus' for the sake of distinction between those theropod tracks which have been included in the ichnotaxonomic concept of the ichnogenus Megalosauripus Lockley, Meyer and dos Santos, 1998 non Lessertisseur, 1955. Because a second morphotype of theropod tracks (Figs. 9c, 16b, 18a, b) is also consistent with the current definition of the latter (Lockley et al. 1998), we use here the name 'Megalosauripus' to distinguish these from 'Bueckeburgichnus'. However, both designations are unsatisfactory in the long term, and this plexus of theropod ichnotaxa is in desperate need of revision.

Yet unpublished material includes other types of theropod tracks which will be listed as "theropod tracks" generally. These include recently discovered didactyl trackways at Obernkirchen, apparently left by theropods with a specialised sickle-shaped claw on digit II (probably troodontids, van der Lubbe et al. 2009, Fig. 16c).

Ornithopoda (Figs. 1, 9d, e, f, 11, 12, 14, 16e, 17a, 18a, b, 19)

Ornithopods are by far the most abundant dinosaurs in the Bückeberg Formation ichnofauna (Fig. 9d, e, f). Even their earliest discoveries have been associated with the genus Iguanodon Mantell, 1825 from the Barremian through Aptian of southern England (Struckmann 1880a, b). Although Struckmann used the descriptive term "Ornithoidichnites" coined by Beckles $(1852,1854)$ for similar tracks from England, most subsequent authors addressed them simply as "Iguanodon tracks" or even as "Iguanodon" (Stechow 1909; Ballerstedt 1914; Lehmann 1978; Richter 2007). It had already been noted by Kuhn (1958) and others that such a designation is taxonomically incorrect, because:

1. it cannot be demonstrated positively that the (geologically younger) orthotaxon Iguanodon had produced the tracks; and

2. naming tracks by the same formal taxonomic group as their producer is only admissible for extant tracks.

Alternatively, the term "iguanodontid tracks" was also used (first by Grabbe 1881). However, this spelling is problematical too, because a monophyletic family Iguanodontidae was not recognised by recent analyses of ornithopod relationships (Norman 2004; Paul 2008; Butler et al. 2008). Nonetheless, attribution of the tracks to (a) relatively large-sized, basal member(s) of Iguanodontia (in the sense of crown-group Ornithopoda, e.g. Norman 2004) is, of course, indisputable.

More recent papers (Lehmann 2003, 2006; Diedrich 2004; U. Richter et al. 2007; Hornung and Reich 2007) recognised the ichnogenus Iguanodontipus Sarjeant, Delair and Lockley, 1998, however without a proper rationale for this assignment. As this ichnogenus was introduced by Sarjeant et al. (1998) for a distinct morphotype of tridactyl ornithopod tracks and not intended as a catch-all ichnotaxon for Lower Cretaceous iguanodontian tracks, its general use for the LSB large ornithopod tracks is rejected herein. Indeed the morphological diversity suggests the presence of at least 2-3 morphotypes among the large ornithopod tracks from the LSB (Hornung unpublished data). These include a new, recently discovered morphotype with two additional metapodial pad impressions at the foot base from Obernkirchen (Böhme et al. 2009, unpublished data).

Because of these complications, ornithopod tracks will not be further differentiated at ichnogenus level in the locality descriptions. Several observations on well-preserved trackways have shown that some of the large ornithopod trackmakers were quadrupedal and various ontogenetic stages are present (Lockley et al. 2004; Diedrich 2004; A. Richter et al. 2007; Böhme et al. 2009; Figs. 9e, f, 16e).

Ballerstedt (1905, 1921a) reported the existence of a didactyl ornithopod track which he named Struthopus schaumburgensis Ballerstedt, 1921. The location of the 
type material of this ichnotaxon is currently not known, but from the published figures it can be inferred that it is not identical to the newly discovered didactyl theropod tracks from Obernkirchen. Given the variation observed in ornithopod tracks from the Obernkirchen Sandstone, it is highly probable that $S$. schaumburgensis is an extramorphologically modified tridactyl track or one left by a pathological individual (as proposed, for example, by Abel 1935). In the latter case, Ballerstedt's ichnotaxon would be justified and valid; however, this can only be decided with the original material at hand.

\section{Small bipedal ornithischians (Fig. 16d)}

Recently, small trackways, possibly left by bipedal cursorial ornithischians have been found at Obernkirchen (Fig. 16d). Their generalised morphology potentially agrees with various groups of ornithischians, including derived ornithopods, basal thyreophorans, and marginocephalians. Detailed studies of these tracks are in preparation.

\section{Ankylosauria (Fig. 9g)}

The first trackway of a quadruped dinosaur from the Bückeberg Formation was described by Ballerstedt (1921b, 1922) from Harrl hill near Bückeburg (Fig. 9g). It was named Metatetrapous valdensis and identified as the trackway of a thyreophoran ornithischian by Nopcsa (1923). The validity and identity of this ichnotaxon were long doubted (Schmidt 1969; Haubold 1974), as the only known documentation of the trackway was a sketch by Ballerstedt (1922). However, recently some parts of the ichnoholotype have been identified from the Ballerstedt collection confirming the observations by Ballerstedt and Nopcsa and supporting its description as an ankylosaurian trackmaker (Hornung et al. 2007, unpublished data).

Non-dinosaurian vertebrate tracks

Non-dinosaurian vertebrate tracks are quite rare in the Bückeberg Formation. Recently, a well-preserved cast of a manus imprint from a large turtle (possibly Hylaeochelys menkei) from the Harrl hill locality was identified in the Ballerstedt collection (Hornung et al. 2008). Diedrich (2004) noted scratch-marks (?swimming-track) made by a crocodilian from the Dinosaurier-Park Münchehagen openair museum quarry but gave no further details or figures.

A strong discrepancy in diversity and composition exists between the vertebrate fauna represented by tracks and by body fossils from the same lithological unit (Table 2). Crocodiles and turtles are very abundant (with a very scarce track record), whereas large ornithopods and theropods (for which an extremely abundant track record
Table 2 Fossil record and taphonomy of tetrapods from the Obernkirchen Sandstone

\begin{tabular}{llll}
\hline Fossil record & \multicolumn{2}{l}{ Body fossils } & Trace fossils \\
\cline { 2 - 3 } Vertebrate Taxa & Preservation & Abundance & Abundance \\
\hline DINOSAURIA & & & \\
Sauropoda & (f) & + & + \\
Theropoda & (f) & + & ++ \\
Ornithischia & & & \\
basal Iguanodontia & (f) & + & +++ \\
Stenopelix valdensis & (a) & + & $?$ \\
Ankylosauria & (f) & + & + \\
CROCODYLIA & (a) & ++ & $?$ \\
CHELONIA & (a) & +++ & + \\
\hline
\end{tabular}

Preservation coded as (a) articulated material, (f) fragmentary and/or isolated material

Abundance: $(+)$ single specimen, extremely rare, $(++)$ few specimens, rare, $(+++)$ numerous specimens

exists) are only represented by a few teeth and isolated bones (Dames 1884a, b; Koken 1887; Struckmann 1894; and unpublished material). This suggests high taphonomical control of both body and trace fossil preservation. The dinosaur tracks represent a local fauna at least temporarily autochthonous to the delta and shoal system (large ornithopods, theropods, rare sauropods, and ankylosaurs). Some body fossils (e.g. Stenopelix valdensis) are allochthonous components from other habitats, which must have existed in the catchment area of local fluvial systems.

\section{Vertebrate tracksites in the Bückeberg formation}

In the sections below, all data about the published dinosaur tracksites from the Obernkirchen Sandstone are compiled. Some emphasis is given to those localities which are currently not accessible and for which data are compiled from the dispersed literature. Localities with current excavation and research coverage are only rather briefly introduced, because their detailed description will be the objective of future work. The locality numbers refer to the map in Fig. 2.

It must be stressed that the rather deliberate use of locality names in the past may have led to confusion. For example, Diedrich (2004) distinguished between two tracksites in the Rehburg Mountains, "Bad Rehburg" (based on Struckmann 1880a, b and Stechow 1909) and "Münchehagen" (based upon Fischer 1998). In fact, Struckmann (1880a, b) referred to specimens found at Wölpinghausen (here locality 4) and Stechow (1909) and Fischer (1998) to material from Münchehagen. Bad Rehburg, situated $1.5 \mathrm{~km}$ E of Münchehagen, has not yielded any tracksite yet. Its use in the older references was 


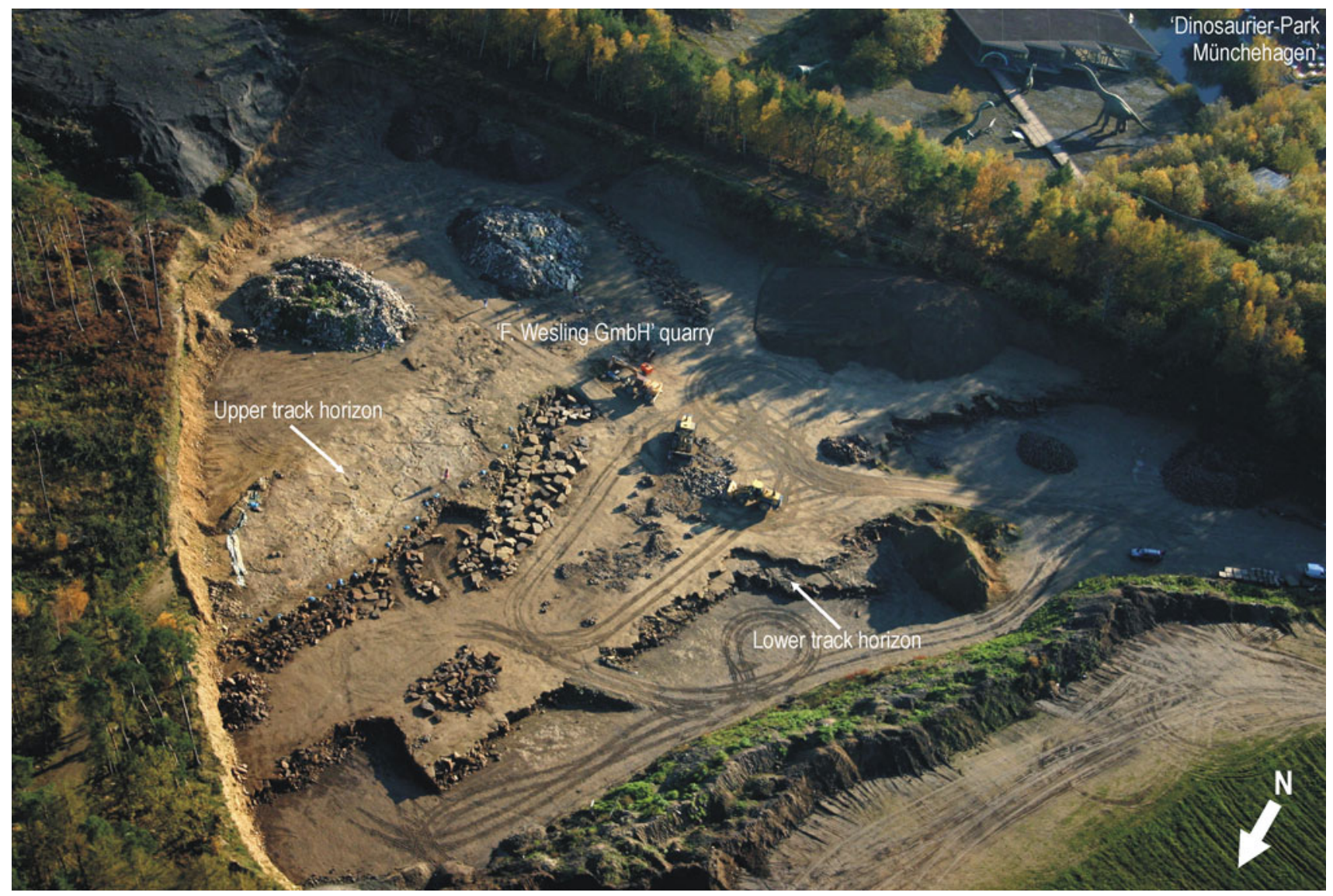

Fig. 10 Münchehagen, F. Wesling GmbH quarry (locality 1) and Dinosaurier-Park Münchehagen open-air museum (locality 2, compare Fig. 6a). Aerial view of the excavations and the exhibitions (in

because of its status as an administration centre (community of Rehburg-Loccum).

\section{Localities 1 to 4: Rehburg Mountains}

Three of the four known tracksites from the Rehburg Mountains (localities 1-3) are clustered in the immediate vicinity $\mathrm{E}$ of the town of Münchehagen. They expose nearly the same stratigraphical interval. At all three outcrops, the succession begins ca $1 \mathrm{~m}$ below the outcrop base with the Hauptflöz coal seam, which is overlain by a sandstone layer with a rugged, eroded surface on top. This discontinuity is found at the same level in all three outcrops (Wilde et al. 1995), and the boundary surface bears dinosaur tracks in two of them (localities 2 and 3). The overlying sandstones are laterally discontinuous and cannot be correlated with certainty.

\section{Münchehagen/F. Wesling GmbH quarry (Figs. 6, 7a, 10, 11)}

Coordinates N 52²6'37.39", E 9 $12^{\prime} 05.90^{\prime \prime}$; R: 3513680 , H: 5812380; 1:25000 German Topographical Map reference grid sheet 3521 Rehburg. the upper right corner) in 2005. The tracks discovered in 1979 are partly protected by the building in the background. Photo by P. Nisi (NLMH)

Stratigraphic position Lower part of Obernkirchen Sandstone, ca 3-5 m above Hauptflöz coal seam.

Track inventory Large and medium-sized ornithopods and theropods.

Remarks The quarry of the F. Wesling GmbH company exposes ca 6-7 m of 0.1-1 $\mathrm{m}$ thick sandstone, intercalated by $0.05-0.2 \mathrm{~m}$ thick mudstone and siltstone layers. Two horizons with well-preserved trackways are present, separated by ca $2 \mathrm{~m}$ of sandstone. Abundant $(>15)$ ornithopod trackways left by bipedal and quadrupedal individuals in various ontogenetic stages were present on both track levels. Several of the animals walked subparallel to each other. One ornithopod trackway consisted of at least 57 steps (Fig. 11). Medium-sized theropods are represented by several trackways on both track horizons. The quarry is still in production; contemporaneous to the quarrying activities, systematic rescue excavations, surveys and casting have been carried out by the Dinosaurier-Park Münchehagen, the NLMH, and collaborating institutions since 2004. As not all track-bearing layers could be preserved, contemporaneously to the documentation of the track-site, a ca 


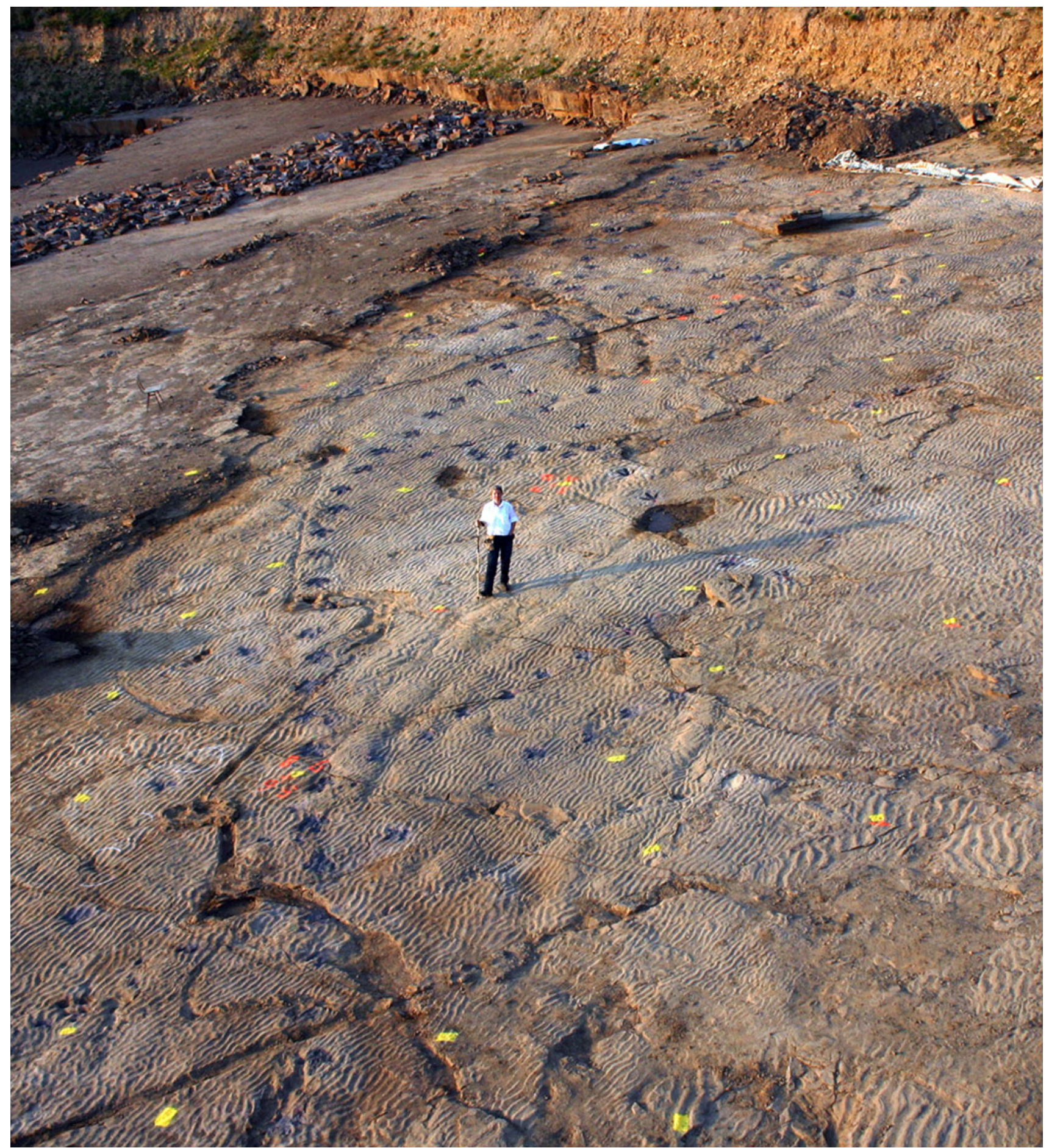

Fig. 11 Münchehagen/F. Wesling GmbH quarry (locality 1), upper track-horizon (large ornithopod trackways) during excavation in 2005. Note the long trackway on the left side and well-preserved

$20 \mathrm{~m}^{2}$-sized slab of the lower track horizon was removed in 2005 for a future exhibit at the GZG. Casts from the 2004-2005 excavation campaigns are stored at the NLMH. Other original material from this locality, already found before systematic excavation at the site began, is on oscillation ripple-marks. After documentation, this area was lost to quarry operations; view towards $\mathrm{N}$

exhibition at the nearby Dinosaurier-Park Münchehagen open-air museum (locality 2) and was partly figured by Lockley et al. (2004). Since 2010, newly excavated at locality 1 , excellently preserved theropod and ornithopod trackways from the lower track horizon are reassembled 
and permanently exhibited in the Dinosaurier-Park Münchehagen protection hall, including currently (spring 2011) a $>15 \mathrm{~m}$ long consecutive trackway of a medium-sized theropod.

References Athen et al. (2005); Wings et al. (2005a, b); Lehmann (2006); Lehmann et al. (2006); A. Richter et al. (2007); U. Richter et al. (2007); Richter (2007).

\section{Münchehagen/Dinosaurier-Park Münchehagen open-air museum (Figs. 6, 10)}

Coordinates N 52²6 $33.20^{\prime \prime}$, E $9^{\circ} 12^{\prime} 02.51^{\prime \prime}$; R: 3513720 , H: 5812190; 1:25000 German Topographical Map reference grid sheet 3521 Rehburg.

Stratigraphic position Lower part of Obernkirchen Sandstone, ca $1 \mathrm{~m}$ above the Hauptflöz coal seam.

Track inventory Sauropods, unidentified tridactyl, bipedal dinosaur, ?crocodile swimming-track.

Remarks The outcrop exposes 7-8 $\mathrm{m}$ of thin- to thickbedded sandstone, interbedded with $\mathrm{cm}$-thick mudstone to siltstone. The Hauptflöz coal seam was found in a core well ca $1 \mathrm{~m}$ below the sandstone layer forming the floor of the quarry (Fischer 1998).

256 individual footprints belong to eight sauropod trackways, seven of which are oriented roughly subparallel. 19 additional footprints form a single trackway of a large tridactyl biped on a single bedding surface. All tracks were pre-diagenetically eroded and further worn by postexcavational damage on the quarry floor before protection. Because of the poor preservation, the producer of the tridactyl track cannot be determined (Lockley et al. 2004). Diedrich (2004) reported "crocodile scratch-marks" from this locality but gave no further details or figure.

On discovery of these tracks in 1979, this tracksite enjoyed great public interest, because it was the first time since the 1920s that long and numerous in situ trackways of dinosaurs had been revealed. It was also the first time sauropod tracks, apparently left by a 'herd', had been identified from the Obernkirchen Sandstone (for overviews see Hendricks 1981; Probst and Windolf 1993; Fischer and Thies 1993, 2000; Fischer 1998). The tracks are protected by conservation law and form the centrepiece of the Dinosaurier-Park Münchehagen open-air museum. Some areas of the tracksite are sheltered and publicly accessible (see also Töneböhn and Kulle-Battermann 1989a, b, c). The tracks have been studied extensively by Hendricks (1981), Kleinschmidt (1986), Fischer (1998) and Lockley et al. (2004). Production in the quarry ceased in 1972.

References Hulke (1980); Hendricks (1981); Staesche (1981); Look (1986); Look et al. (1988); Kleinschmidt
Fig. 12 Wölpinghausen (locality 4). Sandstone block with numerous ornithopod and theropod tracks (hypichnial casts, GZG.IF.00100). Size: ca $178 \times 150 \mathrm{~cm}$. On exhibition in the GZG Geopark, Göttingen (donation of the Principality of Schaumburg-Lippe, second half, nineteenth century)

(1986); Fischer (1987, 1998); Meyer (1987); Fischer et al. (1988); Töneböhn and Kulle-Battermann (1989a, b, c), Fischer in Boenigk (1990); Probst and Windolf (1993); Fischer and Thies (1993, 2000); Haubold in Lockley (1993); Wilde et al. (1995); Mutterlose (1997b); Lockley and Meyer (2000); Lockley et al. (2004); Wright (2005); U. Richter (2007).

\section{Münchehagen/Stadtländer quarry (Fig. 6)}

Coordinates N 52 $26^{\prime} 32.57^{\prime \prime}$, E $9^{\circ} 11^{\prime} 51.37^{\prime \prime}$; R: 3513540 , H: 5812160; 1:25000 German Topographical Map reference grid sheet 3521 Rehburg.

Stratigraphic position Lower part of Obernkirchen Sandstone, ca $4 \mathrm{~m}$ above Hauptflöz coal seam.

Track inventory Large ornithopods(?).

Remarks The quarry exposed ca $9 \mathrm{~m}$ of medium- to thick-bedded sandstone, interbedded infrequently by $\mathrm{cm}$ thick mudstone layers. Layers with accumulated sharkteeth, preserved as impressions, have been reported from this site.

Large tridactyl hypichnia, "probably made by Iguanodon", were observed by Wilde et al. (1995) and Pelzer (1998) at the basal horizon (corresponding to the track horizon in locality 2) and in a second horizon ca $3 \mathrm{~m}$ above the base of the outcrop. The quarry is abandoned, overgrown by vegetation, and partly water-filled.

References Wilde et al. (1995); Pelzer (1998).

\section{Woilpinghausen/Wölpinghäuser Berg (Figs. 1, 12)}

Coordinates Wölpinghäuser Berg (Wilhelmsturm),

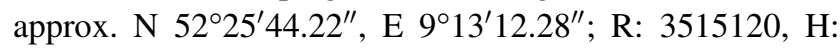
5810660; 1:25000 German Topographical Map reference grid sheet 3521 Rehburg.s

Stratigraphic position Obernkirchen Sandstone, exact level unknown.

Track inventory Large and medium-sized ornithopods, theropods.

Remarks The first scientifically described record of any dinosaur track from Germany was reported from this locality (Struckmann 1880a, b; Fig. 1). Struckmann reported the presence of ca 40 tridactyl, "bird-like" tracks 


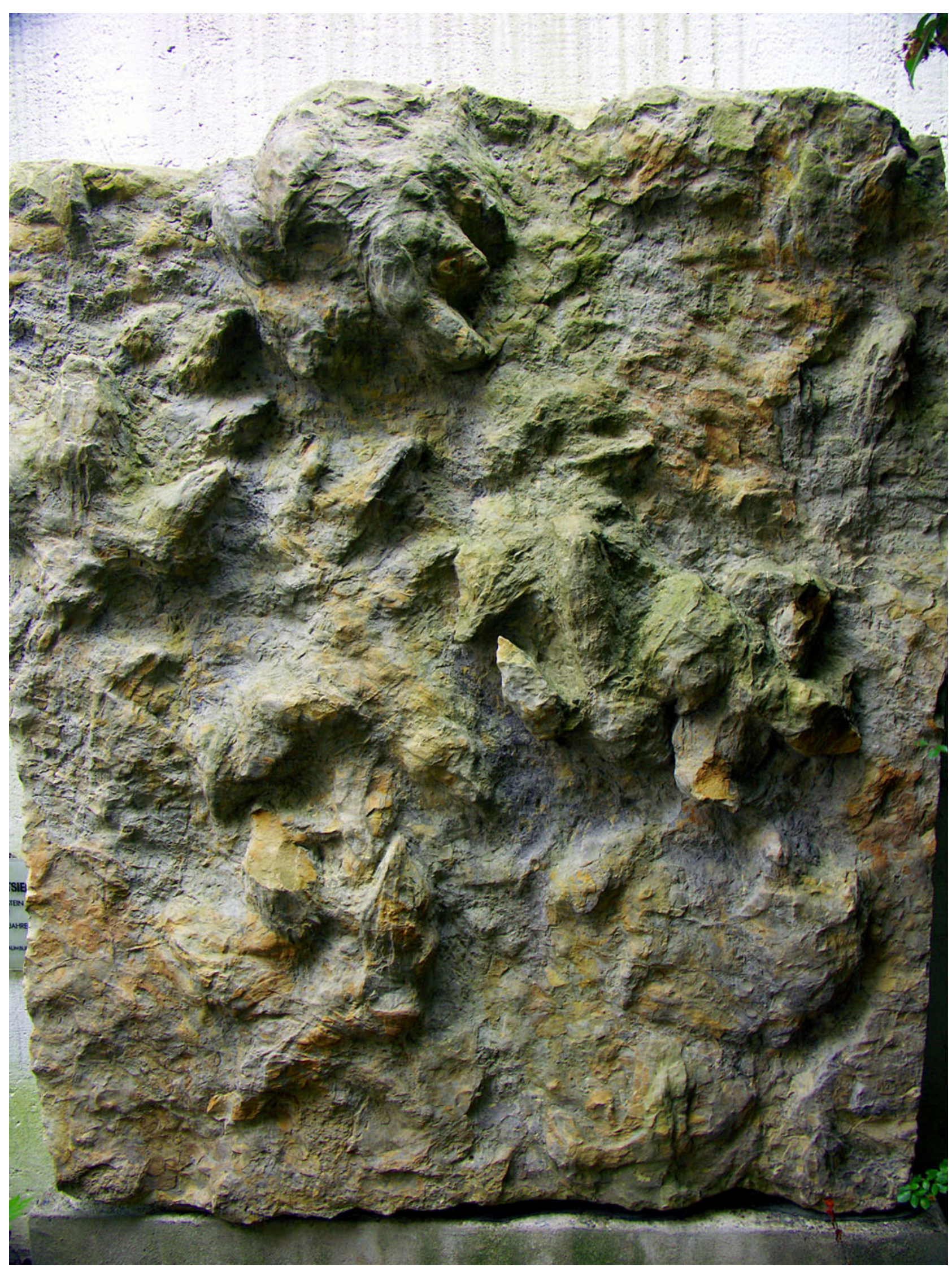


of a biped at the quarry of A. Spörl, close to the Wilhelmsturm, ca $1.5 \mathrm{~km} \mathrm{NW}$ to the town of Wölpinghausen. For some of them the footlength was ca $60 \mathrm{~cm}$. Struckmann $(1880 \mathrm{a}, \mathrm{b})$ provided depictions of isolated hypichnial casts corresponding to large ornithopod tracks, which he associated with the genus Iguanodon (Fig. 1b).

Unfortunately, geological information about the tracksite provided by Struckmann is very sparse. He noted the footprints from two 40-60 cm thick sandstone beds near the base of the quarry, exposing ca $6 \mathrm{~m}$ of Obernkirchen Sandstone. Today the quarry is abandoned and inaccessible.

The GZG houses a large sandstone slab from "Wölpinghausen" (donation of the Principality of SchaumburgLippe; mentioned in Schmidt 1959), lacking more precise locality information. The lower surface is densely covered with hypichnia of mid-sized to large ornithopods and theropods, heading in various directions (Fig. 12).

References Struckmann (1880a, b); Schmidt (1959).

Localities 5 and 6: Bückeburg/Harrl hill

\section{Bückeburg/Abandoned quarry on the W' side of Harrl hill (Fig. 7d)}

Coordinates N $52^{\circ} 15^{\prime} 03.70^{\prime \prime}$, E $9^{\circ} 03^{\prime} 50.71^{\prime \prime}$; R: 35044670 H: 5790870; 1:25000 German Topographical Map reference grid sheet 3720 Bückeburg, ca $1.4 \mathrm{~km}$ SE of Bückeburg.

Stratigraphic position Upper part of Obernkirchen Sandstone.

Track inventory Tridactyl, bipedal dinosaurs.

Remarks The quarry exposed a ca $7.5 \mathrm{~m}$ thick succession showing a tripartite subdivision (Pelzer 1998; Fig. 7d). The lower, $>4.7 \mathrm{~m}$ thick succession consists of medium-bedded, scoured, and partly cross-stratified sandstone with root-traces in the upper part, overlain concordantly with ca $0.8 \mathrm{~m}$ of sandy siltstone and mudstone with ripple-mark cross-lamination and root horizons, topped by a thin coalseam. The upper, ca $2 \mathrm{~m}$ thick unit consists of thin to medium-bedded, cross-stratified, scoured, fine-grained sandstone, rich in molluscs (Neomiodontidae and unidentified gastropods), beginning with a basal coarse-grained horizon with intraformational rip-up clasts, wood impressions, and abundant large bivalve shallow-burrowing traces (Lockeia isp., personal observation).

Pelzer (1998) reported cross-sections of hypichnia in the quarry wall, near the base of the second unit, ca $1.3 \mathrm{~m}$ below the coal seam (Fig. 7d). The track-bearing horizon is probably equivalent to the track layer in nearby locality 6 , excavated by Ballerstedt (e.g. 1905, 1921b). The quarry is abandoned and over-grown by vegetation, but still accessible (personal observation 08/2009).

References Pelzer(1998).

\section{Bückeburg/Hexenteich quarry}

Coordinates N 52 $15^{\prime} 01.16^{\prime \prime}$, E 9 $04^{\prime} 07.62^{\prime \prime}$; R: 3504770 H: 5790734; 1:25000 German Topographical Map reference grid sheet 3720 Bückeburg, ca $1.6 \mathrm{~km} \mathrm{SE}$ of Bückeburg.

Stratigraphic position Upper part of Obernkirchen Sandstone.

Track inventory Large ornithopods (including Struthopus schaumburgensis Ballerstedt, 1921), theropods ('Bueckeburgichnus' maximus Kuhn, 1958), ankylosaurs (Metatetrapous valdensis Nopcsa, 1923), turtle footprint.

Remarks During the 19th century, this locality has yielded important body fossils, for example the holotypes of the crocodylian Pholidosaurus schaumburgensis and the dinosaur Stenopelix valdensis. First discoveries of tracks in the Harrl hill area date back to Grabbe (1881, 1883), but these lack detailed locality information. Around 1900, an extensive track horizon was discovered by Ballerstedt (1905). The material includes large ornithopods and large theropods, among them the type material of 'Bueckeburgichnus' maximus Kuhn, 1958 and Struthopus schaumburgensis Ballerstedt, 1921. Isolated hypichinia from this track horizon survived in the Ballerstedt collection at the GZG and in other places.

In 1921, Ballerstedt reported a trackway of a quadruped from the same locality and horizon (the first definite evidence of a quadruped known from the Obernkirchen Sandstone at the time). This trackway is, historically, the earliest named trackway attributed to an ankylosaur (Metatetrapous valdensis Nopcsa 1923; Hornung et al. 2007).

The strata exposed in this outcrop follow the strike direction of the strata from locality 5 , which is located only $350 \mathrm{~m}$ to the $\mathrm{W}$. The beds can be partly correlated between the two outcrops. The lower part of the exposed section consists of $>8 \mathrm{~m}$ of scoured, medium-bedded, partly crossstratified, fine- to medium-grained sandstone, overlain by ca $0.6 \mathrm{~m}$ of thin-bedded sandstone to mudstone, capped by a cm-thick coal seam. The coal is truncated erosively and overlain by ca $1.7 \mathrm{~m}$ of thin- to medium-bedded, finingupward, cross-stratified sandstone that forms very gently dipping foresets. Above the sandstone, ca $1 \mathrm{~m}$ of siltstone to mudstone is followed by sandstone $0.5 \mathrm{~m}$ thick.

According to Grupe (1933), the succession is underlain by another thin coal seam and the base of the sandstone 
above the coal-seam is rich in stem-fragments of the pteridophyte Tempskya schimperi Corda, 1845 and contains rip-up coal clasts. The dinosaur tracks were confined to the section below the upper coal seam. The central section, including the coal seam and the underlying fine-grained deposits, correlates with the exposure at locality 5 . The lithology of the track casts preserved at the GZG suggests that they were found in this subunit below the coal seam, from were Pelzer (1998) also reported track casts at locality 5.

The quarry near the Bückeburg Castle was owned by the Count of Schaumburg-Lippe in the 19th century. Therefore it was cited in older literature as "Fürstlicher Steinbruch" ("comital quarry") or simply as "the large quarry on the Harrl (hill)" (von Meyer 1841, 1857; Ballerstedt 1905, 1914, 1921a, 1921b, 1922). Regular operations in the quarry ceased around 1870, and it was exploited only occasionally (on demand) into the first half of the 20th century (Ballerstedt 1921). Today the quarry is partly overgrown by vegetation and occupied by the 'Hexenteich' ('witch pond') but is still accessible (personal observation 08/2009).

References von Meyer (1841, 1857, 1859); Ballerstedt (1905, 1914, 1921a, b, 1922); Wegner (1913, 1926); Grupe (1933).

Localities 7 to 11: Bückeberge

\section{Obernkirchen/Schauenstein glass factory quarry}

(Figs. 13, 14)

Coordinates N 52 $15^{\prime} 37.93^{\prime \prime}$, E $9^{\circ} 08^{\prime} 36.80^{\prime \prime}$; R: 3509887 H: 5791918, 1:25000; German Topographical Map reference grid sheet 3720 Bückeburg, ca $1.5 \mathrm{~km} \mathrm{SE}$ of Obernkirchen.

Stratigraphic position Upper part of Obernkirchen Sandstone.

Track inventory Large ornithopods (tridactyl and tetradactyl(?) tracks).

Remarks Dietrich (1927) gave a short description of the locality as of June 1926 (Fig. 13): The succession shows a subdivision into two superimposed lithofacies. The upper, track-bearing lithofacies consists of thin- to medium-bedded, laterally irregular-continuous or lenticular, partly cross-stratified sandstone, intercalated with thin-bedded sandy mudstone. This succession was underlain by thickbedded sandstone and overlain by a thin, discontinuous coal-seam. Dietrich (1927) reported a thickness of $12 \mathrm{~m}$, implying that this thickness referred to the upper, crossstratified horizon. However, comparison with other data from surrounding outcrops and the schematic log by Grupe (1933: fig. 1), suggest that this corresponded rather to the total exposed thickness in the quarry. The cross-stratified lithofacies (below the coal-seam) therefore accounts for $>3-4 \mathrm{~m}$ and the underlying thick-bedded facies for ca 8-9 $\mathrm{m}$, of which only the upper ca $5 \mathrm{~m}$ were exposed in the quarry. The underlying strata down to the UHS were identified from a well in the quarry area (Grupe 1933).

The quarry exposed at least three track horizons, one of which (from the upper lithological unit) was mapped in detail by Dietrich (1927). He identified approximately 40-45 individual tridactyl tracks but was unable to identify longer trackways of consecutive footsteps (Fig. 12). Hamm
Fig. 13 Obernkirchen/ Schauenstein glass factory quarry (locality 7). Uppermost track horizon as mapped by Dietrich 1927: fig. 1. A, $B$ Covered areas of the track horizon; $C$ track surface, sandstone with local oscillation ripple-marks; vertically striated areas were covered by some $\mathrm{cm}$ of mudstone, thinning in the stippled areas; $a-e$ single trackway of a large ornithopod, $f, g$ various other tridactyl tracks

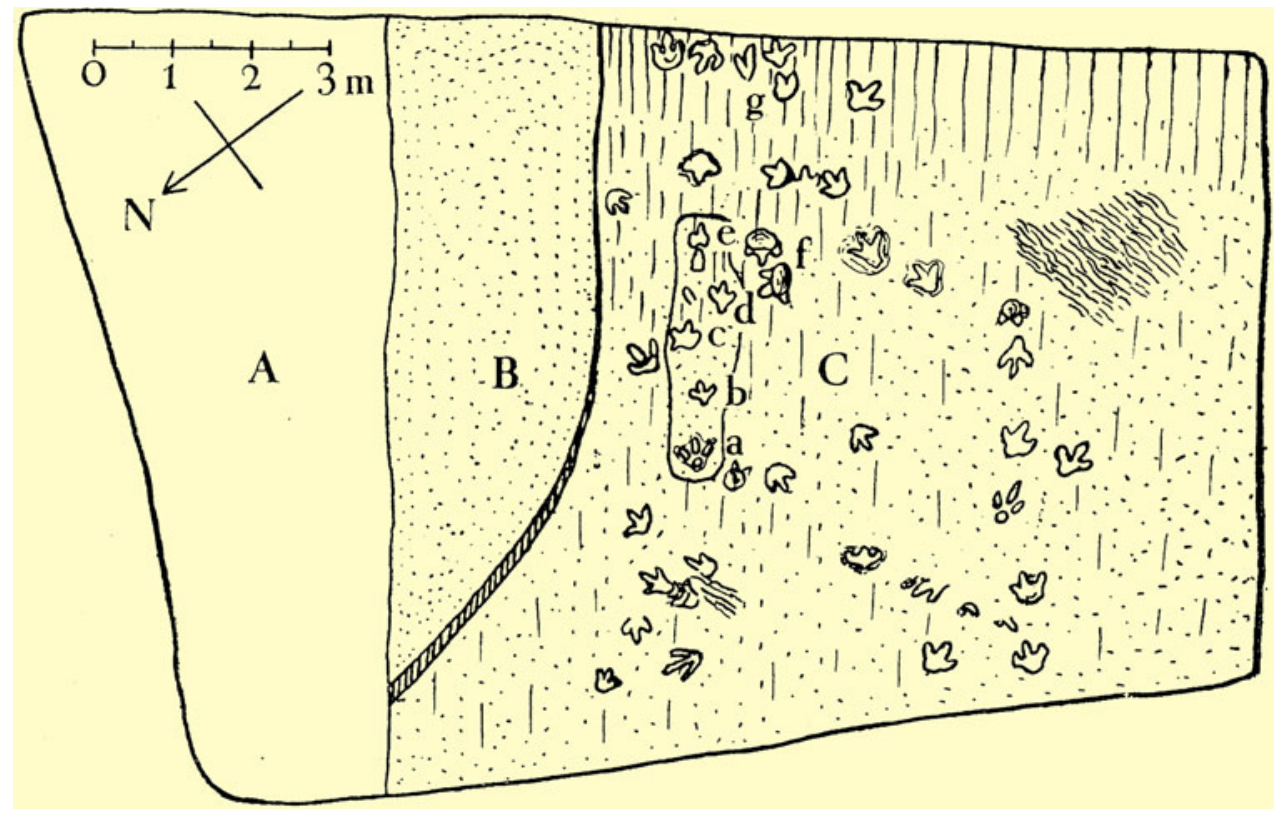


Fig. 14 Obernkirchen/ Schauenstein glass factory quarry (locality 7). Large ornithopod trackway, foot length ca $35 \mathrm{~cm}$, stride length ca $140 \mathrm{~cm}$. Photographed in 1925 , measurements from Hamm 1957

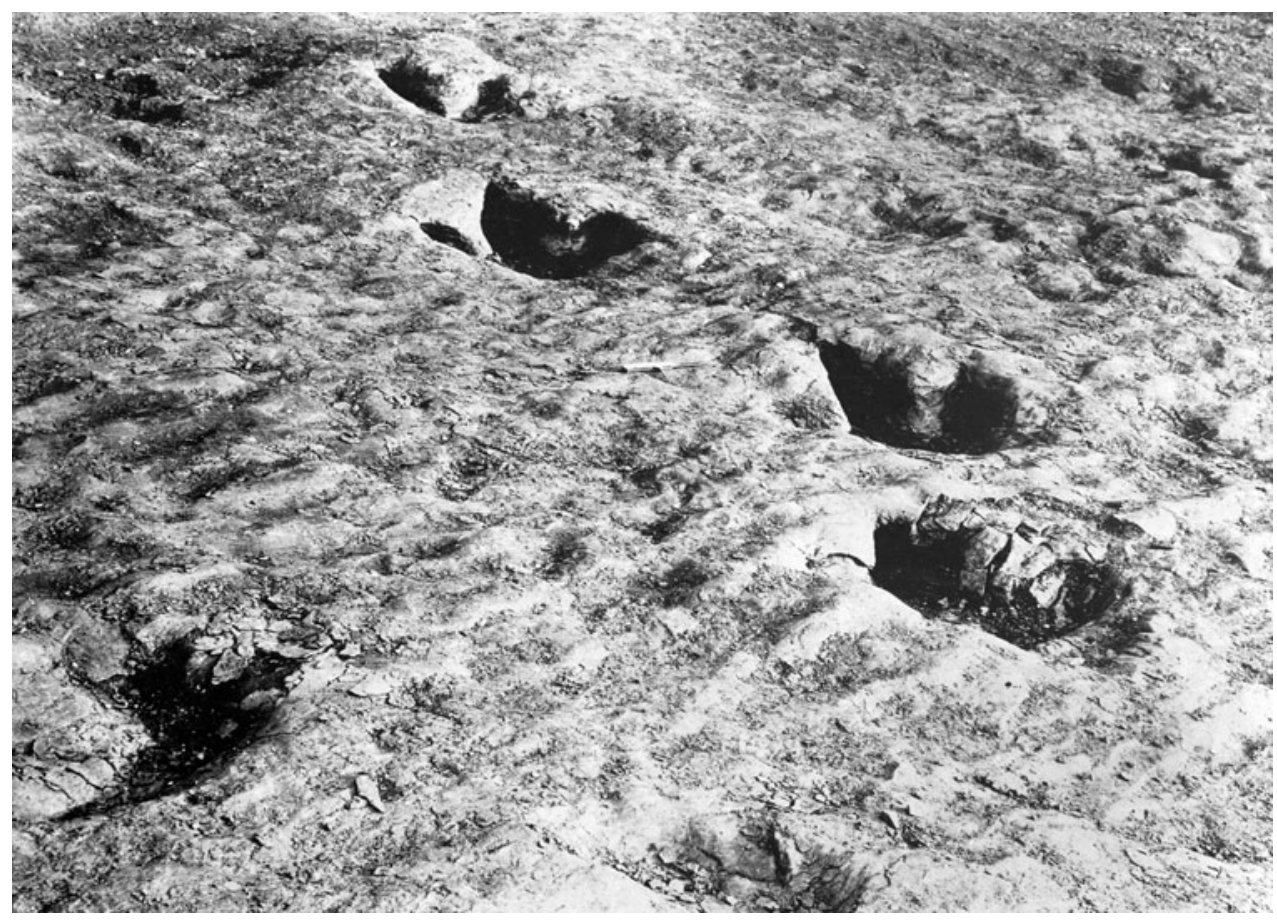

(1957) published a contemporary photograph, apparently showing a part of Dietrich's track horizon, and some measurements (Fig. 14).

The tracks were identified as having been produced by a single taxon of large ornithopods but their shape and quality strongly depends on the local thickness of the sandy mud in which the tracks were left. In some areas they were impressed through the mud-layer into relatively clean sand, where only subtle marks were left. From isolated hypichnia, Dietrich (1927) also figured an allegedly tetradactyl ornithopod pes print, which was named Wealdenichnites iguanodontoides by Kuhn (1958; Fig. 9d). The existence of this morphotype was questioned by Haubold $(1974,1984)$.

Based upon the vertical succession of lithofacies, the track-bearing section can be correlated with the upper part of the exposure in the nearby active quarry of the Obernkirchener Sandstein (locality 8, Fig. 5). The Schauenstein quarry was operated by the F.C.H. Heye glass manufacturing company from 1827 . It is now abandoned and re-filled as an earth dump.

References Dietrich (1927); Grupe (1933); Hamm (1957).

\section{Obernkirchen/Obernkirchener Sandsteinbrüche GmbH quarry (Figs. 7b, $c, 15,16$ )}

Coordinates Main site: N 52 ${ }^{\circ} 15^{\prime} 45.02^{\prime \prime}$, E $9^{\circ} 12^{\prime} 24.16^{\prime \prime}$; R: 3514120 H: 5792220 ; nearby small, inactive quarry: N $52^{\circ}$ 15'37.22", E $9^{\circ} 12^{\prime} 00.34^{\prime \prime}$; R: 3513720, H: 5791940;
1:25000 German Topographical Map reference grid sheet 3721 Auetal, ca $5.3 \mathrm{~km}$ ESE of Obernkirchen.

Stratigraphic position Middle to upper part of Obernkirchen Sandstone.

Track inventory Small, bipedal ornithischians, several morphotypes of large ornithopods and theropods ('Bueckeburgichnus' maximus, 'Megalosauripus' isp., and didactyl tracks).

Remarks The active quarry of the Obernkirchener Sandsteinbrüche $\mathrm{GmbH}$ is currently the most important production site for the Obernkirchen Sandstone. The exposed section comprises more than $8 \mathrm{~m}$ and can be subdived into two vertically stacked lithofacies units (Fig. 7b). The lower, at least $6 \mathrm{~m}$ thick, unit consists of massive, locally channellised (Fig. 7c), thick bedded sandstone with irregular bedding surfaces, abundant rooted palaeosol horizons, and few $\mathrm{cm}$-thick mudstone intervals. The upper unit comprises more than $2 \mathrm{~m}$ of scoured or channellised, lenticular, or planar-bedded, laterally discontinuous sandstone, interbedded with $\mathrm{mm}$ - to cm-thick mudstone layers.

At least six to seven track horizons are present: five to six in the lower lithofacies unit and one in the upper. The lowermost track level, ca 1.5-2 $\mathrm{m}$ above the base of the exposure, comprises hundreds of tri- and didactyl theropod and tridactyl ornithopod tracks of different sizes and morphologies (Figs. 7b, 16a), some still showing long, superimposed trackways. This horizon, which was 
Fig. 15 Locality map of the Obernkirchener

Sandsteinbrüche $\mathrm{GmbH}$ quarry (locality 8 ) figured by Diedrich (2004: figs. 2-3) is situated in the inactive quarry to the SW. Most other discoveries, including the excavations since 2006, were made in the large, active quarry. A map legend is given in Fig. 6a

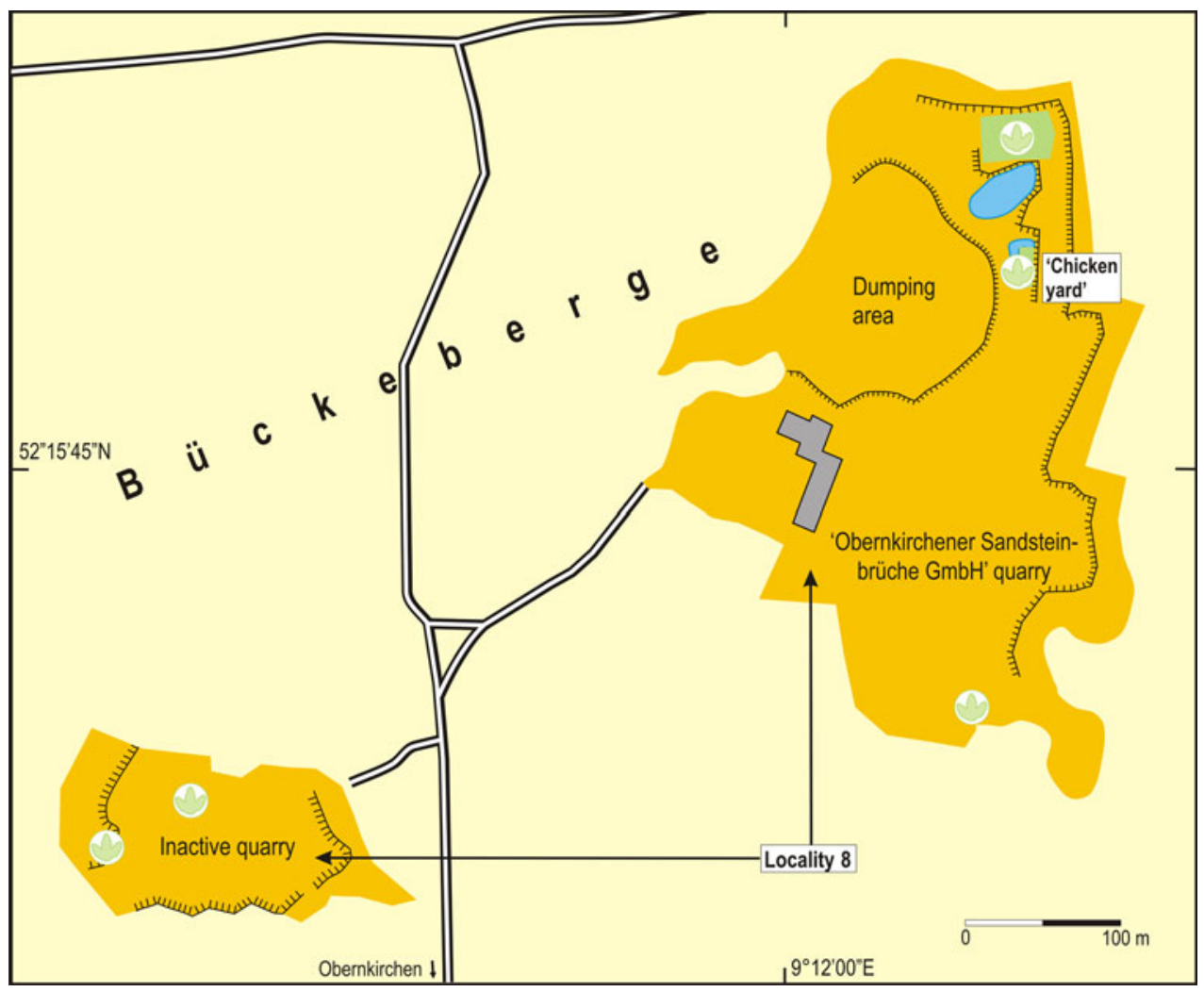

nicknamed 'chicken yard' during excavation (Richter et al. 2009; van der Lubbe et al. 2009), can be traced throughout wide areas in the northern, deepest part of the quarry. Circa $1 \mathrm{~m}$ above the "chicken yard" level, another track horizon, with large ornithopod tracks, has been recognised in a few places.

The uppermost track horizon within the lower unit at the active quarry contains large ornithopod tracks of a new morphotype yet to be described in detail (Böhme et al. 2009). The stratigraphically youngest track level at Obernkirchen is located within the upper unit. Finally, at least one horizon with ornithopod tracks has recently been found in the southern part of the active quarry. The exact stratigraphic position of this horizon has not yet been established, because this area is affected by some faulting, but it seems to be situated in the lower unit.

The track levels reported by Diedrich (2004) are not exposed in the main quarry but in a small, currently inactive quarry ca $500 \mathrm{~m}$ to the $\mathrm{SW}$. We suppose that the bipartite lithofacies subdivision observed by Diedrich (2004: figs. 2-3) at this site corresponds to the lower and upper lithofacies units in the main quarry. Only his "track bed I" was found at the site, as indicated in Diedrich (2004), ca $2.5 \mathrm{~m}$ below the top of the lower lithological unit. A second track layer occurs ca $1 \mathrm{~m}$ lower in the succession than indicated in Diedrich (2004: fig. 3) and nearly $2 \mathrm{~m}$ below the position indicated in Diedrich (2004: fig. 2). Diedrich's "track bed II" could not be found in any of the positions given. In the same locality, isolated large ornithopod tracks were found at the top bed of the lower unit, indicating a third track level.

The gross lithostratigraphic succession in the Obernkirchener Sandsteinbrüche GmbH quarry is very similar to that in the Schauenstein glass factory quarry (locality 7 , Dietrich 1927; Grupe 1933), and the boundary between the lower and upper subunits may correlate. Unfortunately, no coal seam is exposed in the former in direct succession with the track horizons. However, a 10-30 cm thick seam (probably the Hauptflöz seam) is tectonically uplifted in the southeastern area of the quarry in relation to the main part, suggesting that it underlies the lower facies unit. The presence of the Hauptflöz coal seam ca $11 \mathrm{~m}$ below the ground level (ca $2-4 \mathrm{~m}$ below the quarry base level) is also confirmed by various wells drilled in the vicinity of the quarry (LBEG 2009).

In recent years, especially since 2006 , the dinosaur track inventory (Fig. 16b-e) of this location has been shown to be of enormous richness in quantity and diversity. U. Lehmann (1978) provided the first extensive description of ornithopod tracks from the Obernkirchen Sandstone since Ballerstedt's era based upon a large track slab from this locality (now at the GPMH). Diedrich (2004) described a large track slab with ornithopod and theropod ('Megalosauripus' isp.) tracks, discovered in 1987. Haderer and Neef (2004) reported new material of 'Bueckeburgichnus' maximus from this locality, for the first time since the 
Fig. 16 Obernkirchen/

Obernkirchener

Sandsteinbrüche $\mathrm{GmbH}$ quarry (locality 8). The 'chicken yard' track horizon as excavated in 2008-2009. a Overview of the bedding surface with hundreds of dinosaur footprints, preserved as epichnial impressions;

b-e Examples of dinosaur footprint morphotypes preserved on the 'chicken yard' track surface; $\mathbf{b}$ cf.

'Megalosauripus' isp., moderately sized, tridactyl theropod pes track. Light shed from the right; c Small, didactyl theropod pes track, probably from a troodontid. Light shed from the right; $\mathbf{d}$ Small, biped ornithischian pes track. Light shed from the lower right; e Large ornithopod track, manus/pes-couple. Light shed from the left. Coin diameter in all figures b-e is $24 \mathrm{~mm}$
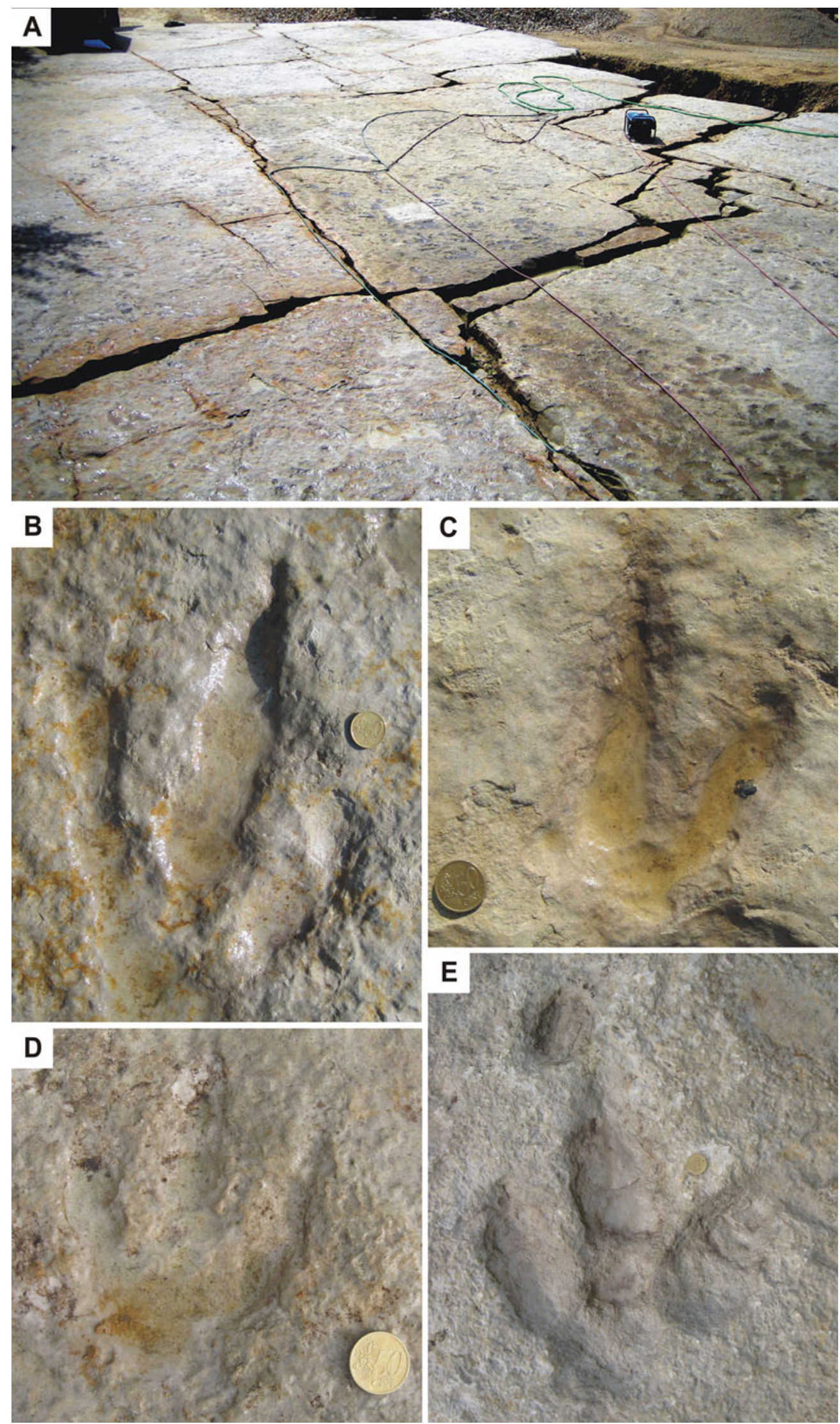
discovery of Ballerstedt's (1905) original material found near Bückeburg. However, the specimen, kept at the $\mathrm{NLMH}$, is very poorly preserved, and its theropod assignment is disputable (personal observation, TvdL, AR). Isolated large slabs at the quarry dump area also preserved large theropod imprints referable to 'Bueckeburgichnus' (personal observation, JJH, MR).

Systematic excavations of the NLMH since 2006 have continuously yielded new finds, among others spectacular mass occurrences of theropod tracks, including didactyl footprints, presumably of troodontids (van der Lubbe et al. 2009). At least four to six ichnotaxa occur at Obernkirchen, partially in the same track layers, therefore providing the highest known diversity of any tracksite in the Obernkirchen Sandstone. Large ornithopods are represented by several trackways (Böhme et al. 2009) including those that indicate quadrupedal individuals (adult and subadult).

A proposal for the partial conservation and public exhibition of this site is under development.

References Broschinski (2004); Diedrich (2004); Haderer and Neef (2004); Lehmann (2003, 2006); Richter and Stratmann (2007); Böhme et al. (2009); van der Lubbe et al. (2009); Richter et al. (2009).

\section{Nienstädt/"Dreier's quarry"}

Coordinates Exact locality unknown. Probably SE to the town of Nienstädt, 1:25000 German Topographical Map reference grid sheet 3721 Auetal.

Stratigraphic position Unknown position within Obernkirchen Sandstone.
Track inventory Tridactyl, bipedal dinosaurs.

Remarks Grabbe (1881) reported moderately sized (footlength $32.9-37.9 \mathrm{~cm}$ ) apparently tridactyl tracks of a biped of "distinct habitus". They were characterised by a "very broad "toe base"" and "triangular toes" of which the middle one was the shortest. Although he provided some measurements, his description-lacking an illustration-is not sufficient to gain a clear picture of this type of tracks. The allegedly short digit III is incongruent to mesaxonic, tridactyl dinosaur pes anatomy and suggests either misinterpretation or an epigenetic modification of the track.

The small, now probably vanished quarry could no longer be located with certainty but was situated SE of the vicinity of Nienstädt.

References Grabbe (1881).

\section{Nienstädt: Liekwegen/Brandshof quarry (Fig. 17)}

Coordinates Approx. N 52 $17^{\prime} 06.50^{\prime \prime}$, E $9^{\circ} 11^{\prime} 25.70^{\prime \prime}$; R: 3512950 H: 5794670; 1:25000 German Topographical Map reference grid sheet 3721 Auetal, ca $1.8 \mathrm{~km} \mathrm{SE}$ of Nienstädt.

Stratigraphic position Unknown position within Obernkirchen Sandstone.

Track inventory Large ornithopods.

Remarks Grabbe (1883) reported large ornithopod tracks (footlength $47-48 \mathrm{~cm}$ ) from this locality, but did not provide any details on the geology or stratigraphy of this, now inaccessible, site. He excavated more that 10 consecutive footprints forming a trail.
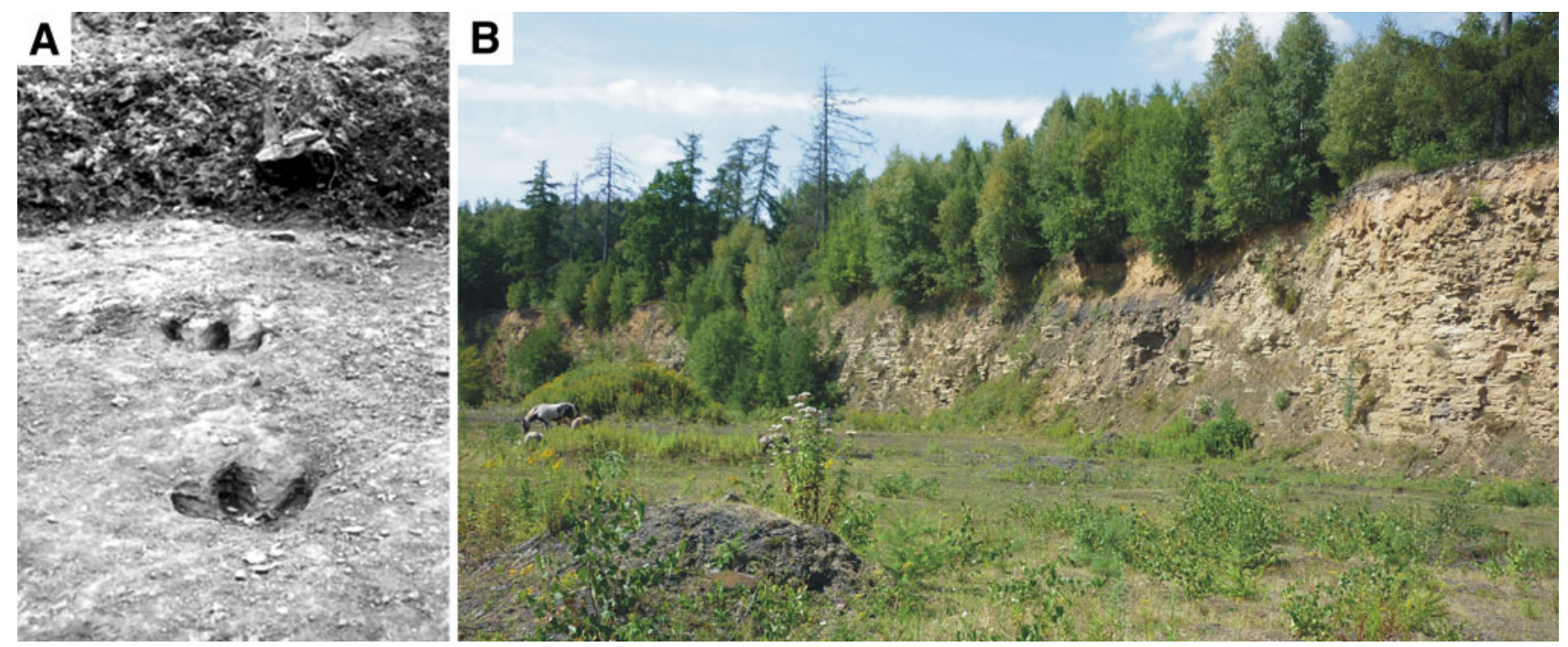

Fig. 17 Liekwegen/Brandshof quarry. a Tridactyl pes track, exact size unknown. Historical photography, ca 1940-1945, GZG museum archive; b Present exposure of the quarry. The base of the quarry consists of sideritic shales with bivalve coquinas, overlain by medium-bedded sandstone. Height of exposure ca 6-7 m, 2009 
An unpublished historical photograph from the 1940s (Fig. 17), labelled "Liekwegen-Wendthagen quarry", shows a tridactyl track of a biped consisting of two pes imprints, preserved as an epichnial relief on an irregular sandstone surface. The morphology and proportions of the track suggest an ornithopod trackmaker. The photograph from the Ballerstedt archive was probably taken at the Brandshof quarry, because of this was the largest quarry in the area and still in production in the mid-20th century. Only a small part of the former quarry is still accessible, exposing ca 4-5 $\mathrm{m}$ of thinning-upward, medium to thinly bedded sandstone. In some places the floor of the quarry consists of sideritic claystone with neomiodontid coquinas underlying the sandstone.

References Grabbe (1883).

\section{Wendthagen/"Maier's quarry"}

Coordinates Exact locality unknown. In the vicinity of the town of Wendthagen, 1:25000 German Topographical Map reference grid sheet 3721 Auetal.

Stratigraphic position Lower or middle part of Obernkirchen Sandstone.

\section{Track inventory Large bipedal dinosaurs.}

Remarks Grabbe (1881) recorded an oral report by mining supervisor Heidtmeier that a ca $100 \mathrm{~m}$ long trail of large footprints was found "well below the top" of the Obernkirchen Sandstone ca 1850-1860. The tracks were preserved as an epirelief. This is the oldest rather detailed and reliable account of dinosaur tracks from Germany. The tracks were no longer preserved at the time of Grabbe's investigations.

\section{References Grabbe (1881).}

\section{Localities 12 and 13: Osterwald}

Tracksites in the Osterwald mountains are located in the more proximal, fluvial and alluvial deposits of the Obernkirchen Member (Pelzer et al. 1992; Pelzer 1998). These deposits cannot be correlated in detail with those of the Obernkirchen Sandstone sensu strictu or dated more precisely than middle or late Berriasian. They are overlain by Valanginian brackish deposits (Osterwald Member).

\section{Osterwald/Quarry $450 \mathrm{~m}$ south of Ahrensberg mountain (Fig. 18)}

Coordinates N52 $7^{\prime} 30.27^{\prime \prime}$, E $9^{\circ} 38^{\prime} 58.70^{\prime \prime}$; R: 3544640 H: 5777050; 1:25,000 German Topographical Map
Fig. 18 Osterwald/Ahrensberg area. Bückeberg Formation, fluvial equivalent of Obernkirchen Member. a Track slab with two, overstepping, large ornithopod trackways (lower part) and theropod footprint (upper right). Parts of a second theropod footprint are located at the upper margin of the slab. Epichnial relief, low-angle light from upper right slab-size approximately $210 \mathrm{~cm} \times 162 \mathrm{~cm}$, BGR unnumbered; b Right and left ornithopod footprints, the trackmakers walked in opposite directions, detail of a; c Left theropod footprint, detail of a. Scale bar $30 \mathrm{~cm}$ (in a), $10 \mathrm{~cm}$ (in $\mathbf{b}$ and $\mathbf{c})$

reference grid sheet 3823 Coppenbrügge (formerly Eldagsen as in Naumann 1927), ca $2 \mathrm{~km} \mathrm{NE}$ to the town of Osterwald.

\section{Stratigraphic position Upper(?) Obernkirchen Member.}

Track inventory Large ornithopods, theropods.

Remarks Naumann (1927) indicated an unspecified number of large, tridactyl hypichnia at the base of a $2.1 \mathrm{~m}$ thick sandstone layer interbedded within a ca $23 \mathrm{~m}$ thick series of alternating sandstone, mudstone, and claystone rich in plant macrofossils and minor coal seams. The succession is located well below the boundary to the Osterwald Member and probably slightly older than that in nearby locality 13 . The track horizons in both localities cannot be correlated lithostratigraphically. The lithofacies and flora suggest a peri-fluvial environment with fine-grained sediments and coal settled in oxbow-lakes and back-swamps, while coarser-grained sedimentary bodies represent channel-fills, natural levees, and crevasse-splay fans (compare Pelzer 1984).

Naumann (1927: 29) explicitly associated the tracks with Iguanodon and reported the recovery of two individual footprints, one with a foot-length of $52 \mathrm{~cm}$ and a foot-width of $42 \mathrm{~cm}$. The quarry is abandoned and over-grown by vegetation.

A ca $2.10 \mathrm{~m} \times 1.62 \mathrm{~m}$ large slab (Fig. 18) of thinly bedded, fine-grained, bioturbated, current ripple-marked sandstone was recovered from the Osterwald/Ahrensberg area (exact provenance unknown) during the 1970s and is now kept at the Bundesanstalt für Geowissenschaften und Rohstoffe, Hannover (BGR). The slab shows three midsized ornithopod footprints (footlength ca $30 \mathrm{~cm}$ ), forming the section of a trackway, and a single well-preserved left footprint of a mid-sized theropod (footlength ca $31 \mathrm{~cm}$ ). The tracks are preserved as epichnia. The small fragment of a second (right) theropod footprint is probably preserved at the upper margin of the slab.

References Naumann (1927).

\section{Osterwald/Kaiserblick (Fig. 19)}

Coordinates $\mathrm{N} 52^{\circ} 7^{\prime} 38.08^{\prime \prime}$, E $9^{\circ} 39^{\prime} 16.00^{\prime \prime}$; R: 3544950 H: 5777260; 1:25000 German Topographical Map reference grid sheet 3823 Coppenbrügge (formerly Eldagsen as 

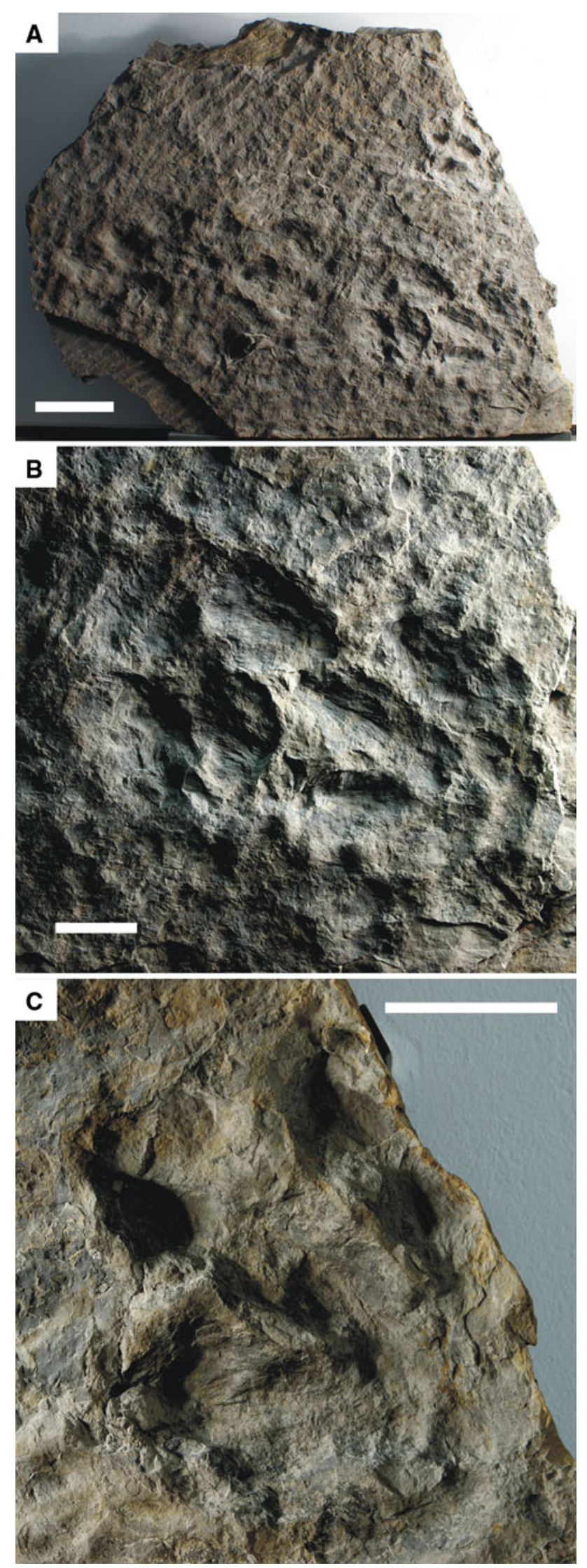

in Naumann 1927), ca $2.4 \mathrm{~km} \mathrm{NE}$ to the town of Osterwald.

Stratigraphic position Upper(?) Obernkirchen Member.

Track inventory Large tridactyl tracks (?Ornithopoda).

Remarks From an abandoned quarry, ca 500 m ESE of the Ahrensberg, Naumann (1927) noted "Iguanodontracks" near the base of a sandstone package, embedded in a ca $20 \mathrm{~m}$ thick succession of sandstone, mudstone, and claystone, and minor coal seams. It is probably slightly younger than that in nearby locality 12 . The lithofacies data provided by Naumann are scarcer than in locality 12 but suggest a similar environmental setting. The quarry is abandoned and over-grown by vegetation.

Barner (1931) published a photograph from the tracksite, taken around 1925 (Fig. 19).

References Naumann (1927); Barner (1931).

\section{The Obernkirchen Sandstone dinosaur track localities- a megatracksite?}

Diedrich (2004) listed several of the above mentioned dinosaur tracksites (localities 2, 4, 6, 8) as forming a "central European Berriasian megatracksite". This argument was mainly based on the (rough) stratigraphical and lithofacial correlation of these localities and the assumed lateral connection of the track-bearing lithological units.

Generally, a megatracksite is strictly defined as a regionally extensive, single track-bearing horizon, or a very thin package of horizons over a large area in the order of hundreds or thousands of square kilometres (Lockley and Pittman 1989; Lockley 1991a). Almost all of the established megatracksites are formed by track-bearing strata not exceeding $1 \mathrm{~m}$ in thickness (Lockley 1997). An exception is provided by the Dakota Sandstone megatracksite (the "dinosaur freeway", Lockley et al. 1992), which consists of several track horizons, encompassing a total thickness of ca $10 \mathrm{~m}$. Regional correlation of the track horizon(s) requires very sound stratigraphic control, as provided, for example, by vertical relationships to major sequence boundaries in clastic sequences or laterally extensive bed-by-bed correlation in carbonate platform successions (Lockley 1991b; Meyer 1993; Kvale et al. 2001).

Such tight stratigraphic control is not available for the Obernkirchen Sandstone tracksites. Although in many locations several trackway horizons are present, these cannot be correlated laterally over more than a few square kilometers at best (Figs. 5, 6b). The sandstone beds on 


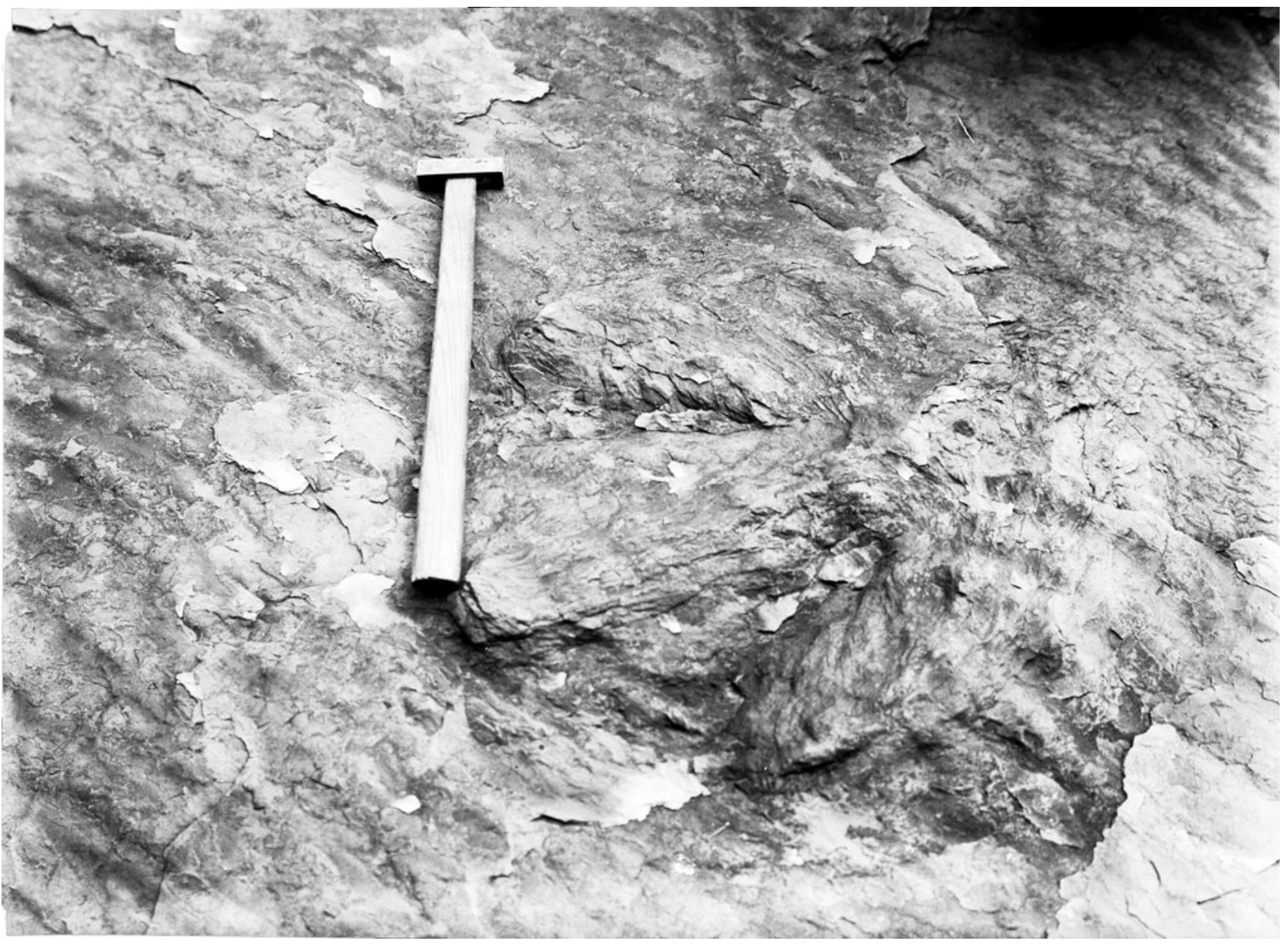

Fig. 19 Osterwald/Kaiserblick (locality 13). Large ornithopod track (hypichnial cast). Historical photograph, 1930 by F. Hamm (from Barner 1931)

which the tracks were preserved are often laterally discontinuous, sometimes even at outcrop scale, and lithofacies assemblages differ among the outcrop regions.

Truncated channel-fill deposits indicate the presence of intraformational discontinuities above the track-level in the Münchehagen quarry (Fischer 1998). A discontinuity at regional scale was also reported from the western Obernkirchen area by Dietrich (1927) and Grupe (1933) and observed in the Obernkirchener Sandsteinbrüche $\mathrm{GmbH}$ quarries (personal observation).

As already discussed, major differences exist between the lithofacies assemblages at the Rehburg Mountains and the Bückeberge. Although both systems were probably genetically coupled on a wider time scale, a strict isochrony of the barrier deposits in the northwest and the deltaic succession in the southwest-and especially of the dinosaur track horizons within both-cannot be demonstrated at present. Although similar in facies, again such a correlation cannot be made between the occurrences at
Harrl hill and the Bückeberge. Therefore, identification of the Obernkirchen Sandstone as a megatracksite currently seems premature and rather uncertain.

\section{Conclusions}

13 dinosaur tracksites have been identified in the Obernkirchen Sandstone (Obernkirchen Member, Bückeberg Formation, Late Berriasian) in the southeastern part of the Lower Saxony Basin, eight of which are no longer accessible. A survey of available geological and ichnological data on these localities shows a database of quite inhomogeneous quality.

Correlations to current facies models (Pelzer 1998) for the Obernkirchen Sandstone and equivalents show that eleven tracksites are located in a distal coastal barrier/ deltaic facies assemblage. 
The presence of dinosaur tracks spans a number of facies types, indicating a range of local environments. Track occurrences in the Münchehagen area are linked to heterolithic successions, reflecting re-occurring highenergy depositional events interrupting long-term calm suspension settling. These events have a local reoccurrence frequency of at least $10^{1}$ to $10^{2} \mathrm{yrs}$, and are related to storm events carrying matured littoral barrier sands into backbarrier lagoons. Dinosaurs must have frequently passed through shallow areas of these lagoons and along barriers and shoals.

At Obernkirchen (Bückeberge), many of the track levels occur at the top of sandbars, which show indications of subaerial exposure and plant coverage. The laterally continuous beds are vertically and laterally intercalated with channel-fill sandstones in places, suggesting a net aggrading, temporarily emergent mouthbar complex. At Harrl hill, well-preserved dinosaur tracks occur on what is interpreted as a submerging mouthbar surface.

Because of association of various facies assemblages, lateral inconsistency, and a lack of stratigraphic correlation of the track-bearing horizons in the Obernkirchen Sandstone, its characterisation as a megatracksite (Diedrich 2004) is currently regarded as speculative.

Two tracksites occur at the Osterwald mountains in more proximal equivalents of the Obernkirchen Sandstone, represented by perifluvial overbank deposits further inland.

Vertebrate clades represented by tracks include Ornithopoda, small, bipedal ornithischians, Ankylosauria, Theropoda, Sauropoda, turtles, and possibly crocodiles. Large ornithopods are most abundant and probably present in all localities, followed in abundance by theropods (five localities), sauropods, ankylosaurs, turtles and crocodiles (one locality each). Several ichnotaxa have been established for these tracks, but, with the exception of Metatetrapous valdensis Nopcsa, 1923 (Ankylosauria; Hornung et al. 2007), none is properly defined at present. There are two or three morphotypes (partly related to different ontogenetic stages) of large ornithopod tracks and at least three morphotypes of theropods (corresponding to different clades). Ornithopod and theropod tracks occur in large numbers in several localities.

A strong discrepancy in diversity and composition exists between the vertebrate fauna represented by tracks and by body fossils from the same lithological unit. This suggests high local vicariance and taphonomical control of both body and trace fossil preservation. The dinosaur tracks represent a local fauna at least temporarily autochthonous to the estuary and shoal system. The nearly total absence of articulated or associated material from these groups suggests that their presence in this environment was probably non-permanent and migratorial.
Acknowledgments The following people provided valuable discussions and logistic help: H. Schwanke (GZG), M. Sosnitza (retired, formerly GZG), T. Stegemann (GZG), H.-V. Karl (Weimar/GZG), J. König (GZG), M. Raddatz (Halle/S.), and U. Staesche (Hannover). $\mathrm{T}$. Wiese (BGR) is thanked for providing access to material in his care. V. J. Roden (formerly GZG) is acknowledged for checking the English spelling and grammar. The current excavation projects in the Obernkirchen Sandstone would not be possible without ongoing and generous support by the owners and crew of the quarry operations. We cordially thank F. Wesling sen. (Ferdinand Wesling GmbH \& Co. KG and Dinosaurier-Park Münchehagen GmbH \& Co. KG, RehburgLoccum), K. Köster (Obernkirchener Sandsteinbrüche GmbH, Obernkirchen), and B. Wolter (retired, formerly Dinosaurier-Park Münchehagen) for their cooperation in our research work, and for their willingness to allow public access to and preservation of the dinosaur tracks found on their property. F. Klebe and L. Seidel (Landkreis Schaumburg-Lippe) also provided interest in and support of conservation of the tracks. The research at Münchehagen is strongly assisted by the team of the "Dinosaurier-Park Münchehagen" open-air museum headed by N. Knötschke. The support by many others was vital to the excavation projects, including M. Schmitz (formerly NLMH, currently Naturhistorisches Museum, Mainz), A. Basse (Bremen), and U. Richter (Hannover), and the volunteer team, joined on a regular basis by U. Stratmann, O. Gerke, U. Picht, G. Picht, J. Picht, C. Weimann, and L. Weimann and hundreds of short-term volunteers who have spent thousands of working-hours uncovering the tracksites at Münchehagen and Obernkirchen since 2004. Colleagues from other research institutions also cooperated in various stages of the project, including M. Wiggenhagen (Institut für Photogrammetrie und Geoinformation, Leibniz-Universität Hannover, Hannover), M. Fischmann, and K. Grobe (Fachbereich Design und Medien, Fachhochschule Hannover, Hannover), O. Wings (Museum für Naturkunde, Humboldt-Universität zu Berlin), J. Lepper (formerly BGR), C. Heunisch, and F. Luppold (Landesamt für Bergbau, Energie und Geologie, Hannover), J. Lehmann (Geowissenschaftliche Sammlung, Universität Bremen), and O. Kullmer (Forschungsinstitut und Naturmuseum Senckenberg, Frankfurt am Main). All of these people are warmly acknowledged for their efforts. We also thank Richard J. Butler (München) and Oliver Wings (Münchehagen/Berlin) for reviewing the manuscript and providing helpful comments to improve the paper.

Open Access This article is distributed under the terms of the Creative Commons Attribution License which permits any use, distribution, and reproduction in any medium, provided the original author(s) and the source are credited.

\section{References}

Abel, O. 1935. Vorzeitliche Lebensspuren. xv+664 pp., Jena: Fischer. Agassiz, L. 1833. Recherches sur les poissons fossiles. Volume I. xlix+188 pp., Neuchâtel: Auteur.

Anonymous. 1879a. [Naturhistorische Gesellschaft...]. Hannoverscher Courier 23 (10023, morning issue; 09 Nov 1879): without pagination. [Newspaper report].

Anonymous. 1879b. Local-Nachrichten, Naturhistorische Gesellschaft [...]. Hannoverscher Courier 23 (10039, evening issue; 19 Nov 1879): 4-5. [Newspaper report].

Anonymous. 2005. Saurierfährte in der Borgloher Schweiz entdeckt. 130 Millionen Jahre alter Abdruck stammt von einem Dreizeher. Landkreis Osnabrück, Pressemitteilung vom 07.09.2005. http://www.landkreis-osnabrueck.de/verwaltung-europa-politik/ pressestelle/pressearchiv $/ 3 . \mathrm{html}$ ?kategorie $=0 \&$ month $=9 \&$ type $=$ search \&view=search\&year=2005 [last accessed: 09 Feb 2009]. 
Arp, G., and C. Mennerich (2008) Ostracod associations, palaeoenvironment and cyclicity of Purbeck-type sediments of the Münder Formation (Lower Cretaceous, Hils Syncline, N-Germany). In Applications of lacustrine and marginal-marine Ostracoda to palaeoenvironmental reconstruction, 15th International Symposium on Ostracoda, eds. S. Mischke, and J. A. Holmes. Palaeogeography, Palaeoclimatology, Palaeoecology 246(3-4): 230-249.

Athen, K., O. Wings, and A. Broschinski. 2005. Wildwechsel von 140 Millionen Jahren. Dinosaurierspuren führen ins Niedersächsische Landesmuseum nach Hannover. Museum Aktuell 118(9): 6-8.

Bachmann, G.H., and S. Grosse. 1989. Struktur und Entstehung des Norddeutschen Beckens-geologische und geophysikalische Interpretation einer verbesserten Bouguer-Schwerekarte. In Das Norddeutsche Becken. Geophysikalische und geologische Untersuchungen des tieferen Untergrundes: Vorträge. Niedersächsische Akademie der Geowissenschaften, Veröffentlichungen 2: 23-47.

Ballerstedt, M. 1905. Über Saurierfährten der Wealdenformation Bückeburgs. Naturwissenschaftliche Wochenschrift (Neue Folge) 4(31): 481-485.

Ballerstedt, M. 1914. Bemerkungen zu den älteren Berichten über Saurierfährten im Wealdensandstein und Behandlung einer neuen, aus 5 Fußabdrücken bestehenden Spur. Centralblatt für Mineralogie, Geologie und Paläontologie 1914(2): 48-64.

Ballerstedt, M. 1921a. Zwei große, zweizehige Fährten hochbeiniger Bipeden aus dem Wealdensandstein bei Bückeburg. Zeitschrift der Deutschen Geologischen Gesellschaft, Monatsberichte 73B: 76-91.

Ballerstedt, M. 1921b. Dinosaurierfährten im Wealdensandstein des Harrl bei Bückeburg und eine zur Zeit freiliegenden Spur eines „vierfüßigen“plumpen Dinosauriers. Zeitschrift der Deutschen Geologischen Gesellschaft 72: 231-233.

Ballerstedt, M. 1922. Über Schreckensaurier und ihre Fußspuren. Kosmos 19(3): 77-80.

Barner, W. 1931. Unsere Heimat Band 1: Das Land zwischen Hildesheimer Wald und Ith. xi+571 pp., Hildesheim: Lax.

Beckles, S.H. 1852. On the Ornithoidichnites of the Wealden. Quarterly Journal of the Geological Society 8(1-2): 396-397.

Beckles, S.H. 1854. On the Ornithoidichnites of the Wealden. Quarterly Journal of the Geological Society 10(1-2): 456-464.

Bennett, S.C. 2007. A review of the pterosaur Ctenochasma: Taxonomy and ontogeny. Neues Jahrbuch für Geologie und Paläontologie, Abhandlungen 245(1): 23-31.

Berner, U. 2011. The German Wealden, an unconventional hydrocarbon play? Erdöl, Erdgas, Kohle 127(7/8): 303-306.

Berner, U., T. Kahl, and G. Scheeder. 2010. Hydrocarbon potential of sediments of the German Wealden Basin. Oil Gas. European Magazine II/2010: 80-84.

Betz, D., F. Führer, G. Greiner, and E. Plein. 1987. Evolution of the Lower Saxony Basin. Tectonophysics 137(1-4): 127-170.

Beyrich, H.E., W. Websky, and O. Speyer. 1879. 2. Protokoll der December-Sitzung. Zeitschift der Deutschen Geologischen Gesellschaft 31: 798-804.

Blumenbach, J.F. 1803. Specimen archaeologiae telluris terrarumque inprimis Hannoveranarum. Göttingen: H. Dieterich.

Boenigk, G. 1990. Geologie im Niedersächsischen Landesmuseum Hannover. Hannover: Niedersächsisches Landesmuseum.

Böhme, A., U. Stratmann, M. Wiggenhagen, T. van der Lubbe, and A. Richter. 2009. New tracks on the rock: Parallel trackways of a new type of Iguanodontipus-Caririchnium-like morphology from the Lower Cretaceous sandstones of Obernkirchen, northern Germany. Journal of Vertebrate Paleontology 29(3): 66A.

Bose, S., and H.S. Chafetz. 2009. Topographic control on distribution of modern microbially induced sedimentary structures (MISS):
A case study from Texas coast. Sedimentary Geology 213: 136-149.

Branco, W. 1887. Beiträge zur Kenntnis der Gattung Lepidotus. Abhandlungen zur geologischen Specialkarte von Preußen und den thüringischen Staaten 7(4): 84 pp.

Broschinski, A. 2004. Exkursion 3: Der Obernkirchner SandsteinNaturwerkstein und Fossilfundgrube der Unterkreide. In Geobiologie 2. 74. Jahrestagung der Paläontologischen Gesellschaft in Göttingen 02. bis 08. Oktober 2004. Exkursionen und Workshops, eds. J. Reitner, M. Reich, and G. Schmidt, 53-72, Göttingen: Universitäts-Verlag.

Butler, R.J., and R.M. Sullivan. 2009. The phylogenetic position of the ornithischian dinosaur Stenopelix valdensis from the Lower Cretaceous of Germany and the early fossil record of Pachycephalosauria. Acta Palaeontologica Polonica 54(1): 21-34.

Butler, R.J., P. Upchurch, and D.B. Norman. 2008. The phylogeny of the ornithischian dinosaurs. Journal of Systematic Palaeontology 6: $1-40$.

Casey, R., P. Allen, G. Dörhöfer, F. Gramann, N.F. Hughes, E. Kemper, P.F. Rawson, and F. Surlyk. 1975. Stratigraphical subdivision of the Jurassic-Cretaceous boundary beds in NW Germany. Newsletters on Stratigraphy 4(1): 4-5.

Corda, A.J. 1845. Beiträge zur Flora der Vorwelt. Prag: Calve.

Dames, W. 1884a. Megalosaurus dunkeri. Sitzungsberichte der Gesellschaft naturforschender Freunde zu Berlin (1884) (10): 186-188.

Dames, W. 1884b. Über ein Humerusfragment eines Dinosauriers welches im Liegenden des Hauptflötzes im Marienschacht auf der Körssen bei Stadthagen gefunden wurde. Zeitschrift der Deutschen Geologischen Gesellschaft 36: 186-187.

Diedrich, C. 2004. New important iguanodontid and theropod trackways of the tracksite Obernkirchen in the Berriasian of NW Germany and megatracksite concept of Central Europe. Ichnos 11(3): 215-228.

Dietrich, O.W. 1927. Über Fährten ornithopodider Saurier im Oberkirchner Sandstein Sandstein. Zeitschrift der Deutschen Geologischen Gesellschaft 78: 614-621.

Dollo, L. 1883. Troisième note sur les dinosauriens de Bernissart. Bulletin du Musée Royal de d'Histoire Naturelle de Belgique 2: 85-126.

Dunker, W. 1846. Monographie der Norddeutschen Wealdenbildung: ein Beitrag zur Geognosie und Naturgeschichte der Vorwelt. Braunschweig: Oehme and Müller.

Dunker, W. 1849. Ueber den norddeutschen sogenannten Wälderthon und dessen Versteinerungen. Studien des Göttingischen Vereins Bergmännischer Freunde 5(2): 105-185.

Edinger, T. 1938. Über Steinkerne von Hirn- und Ohr-Höhlen der Mesosuchier Goniopholis und Pholidosaurus aus dem Bückeburger Wealden. Acta Zoologica 19(3): 467-505.

Elstner, F., and J. Mutterlose. 1996. The Lower Cretaceous (Berriasian and Valanginian) in NW Germany. Cretaceous Research 17(1): 119-133.

Eriksson, P.G., J. Schieber, E. Bouougri, G. Gerdes, H. Porada, S. Banerjee, P.K. Bose, and S. Sakar. 2007. Classification of structures left by microbial mats in their host sediments. In Atlas of microbial mat features preserved within the clastic rock record, ed. J. Schieber, J. Bose, P.K. Eriksson, B.G. Banerjee, S. Sarkar, W. Altermann, and O. Catunaeau, 39-52. Amsterdam: Elsevier.

Falke, H. 1944. Der Wealden-Steinkohlenbergbau in Niedersachsen. Veröffentlichungen des Provinzialinstituts für Landesplanung und niedersächsische Landes- und Volksforschung HannoverGöttingen (A: Forschungen zur Landes- und Volkskunde, I: Natur und Wirtschaft) 23: 130 pp.

Farlow, J.O., J.G. Pittman, and M. Hawthorne. 1989. Brontopodus birdi, Lower Cretaceous sauropod footprints from the U.S. Gulf 
Coastal Plain. In Dinosaur tracks and traces, ed. D.D. Gillette, and M.G. Lockley, 371-394. Cambridge: Cambridge University Press.

Fischer, R. 1987. Exkursion V-1. Bedeutende paläontologische Lokalitäten im östlichen Niedersachsen. In 57. Jahrestagung der Paläontologischen Gesellschaft, Exkursionsführer Harz und Harzvorland, 2-26, Clausthal-Zellerfeld: Institut für Geologie und Paläontologie.

Fischer, R. 1998. Die Saurierfährten im Naturdenkmal Münchehagen. Mitteilungen aus dem geologischen Institut der Universität Hannover 37: 3-59.

Fischer, R., and D. Thies. 1993. Das Dinosaurier-Freilichtmuseum Münchehagen und das Naturdenkmal „Saurierfährten“, 1st ed., 60 pp., Rehburg-Loccum.

Fischer, R., and D. Thies. 2000. Das Dinosaurier-Freilichtmuseum Münchehagen und das Naturdenkmal „Saurierfährten“, 2nd ed. Rehburg-Loccum: Dino-Park Münchehagen.

Fischer, R., S. Kulle-Battermann, and R. Töhneböhn. 1988. Das "Naturdenkmal Saurierfährten Münchehagen". Natur und Museum 118(12): 385-392.

Grabbe, H. 1881. Neue Funde von Saurier-Fährten im Wealdensandsteine des Bückeberges. Verhandlungen des naturhistorischen Vereines der preussischen Rheinlande und Westfalens, Correspondenzblatt 38(1): 161-164. (=Vierte Folge volume 8).

Grabbe, H. 1883. Die Schaumburg-Lippe'sche Wealden-Mulde. Doctoral thesis, University of Göttingen, 61 pp., Bückeburg: Grimme.

Grabbe, H. 1884. Beitrag zur Kenntnis der Schildkröten des deutschen Wealden. Zeitschrift der Deutschen geologischen Gesellschaft 36: 17-28.

Gramann, F., C. Heunisch, H. Klassen, F. Kockel, G. Dulce, F.-J. Harms, T. Katschorek, E. Mönnig, M. Schudack, U. Schudack, D. Thies, and M. Weiss. 1997. Das Niedersächsische OberjuraBecken-Ergebnisse interdisziplinärer Zusammenarbeit. Zeitschrift der Deutschen Geologischen Gesellschaft 148(2): 165-236.

Graupner, A. 1977. Natursteine an hannoverschen Bauwerken. Hannoversche Geschichtsblätter 35: 103-152.

Graupner, A. 1980. Der Berrias-Steinkohlenbergbau in Niedersachsen 1945-1963. Veröffentlichungen des niedersächsischen Instituts für Landeskunde und Landesentwicklung an der Universität Göttingen. Forschungen zur niedersächsischen Landeskunde 116: $184 \mathrm{pp}$.

Grupe, O. 1931. Über Wurzelböden im Wealdensandstein der Bückeberge und ihre Bedeutung für den Rhythmus dynamischer Vorgänge. Zeitschrift der Deutschen Geologischen Gesellschaft 83: 224-234

Grupe, O. 1933. Blatt Bückeburg, Nr. 2017. Erläuterungen zur geologischen Karte von Preußen und benachbarter deutscher Länder, Lieferung 330: 69 pp.

Haderer, F., and C. Neef. 2004. Ein weiterer Nachweis der Theropodenfährte Bueckeburgichnus aus dem Obernkirchener Sandstein von Nordwestdeutschland. Bericht der Naturhistorischen Gesellschaft Hannover 146: 1-6.

Hamm, F. 1938. Einführung in Niedersachsens Erdgeschichte. 333 pp., Hildesheim and Leipzig: Lax.

Hamm, F. 1957. Letzte Spuren großer Landechsen in Niedersachsen. Niedersachsen Zeitschrift für Kultur, Geschichte, Heimat und Natur 3: 209-212.

Harnack, I. 1989. Der 'Bremer Stein'-Ein Stein macht Geschichte. Begleitheft zur Sonderausstellung im Übersee-Museum vom 5.2. bis 2.4.1989. Bremen: Übersee-Museum.

Haubold, H. 1971. Ichnia Amphibiorum et Reptiliorum fossilium. Handbuch der Paläoherpetologie 18: 124 pp.

Haubold, H. 1974. Die fossilen Saurierfährten. Die neue BrehmBücherei 479: 168 pp., Wittenberg: Ziemsen.
Haubold, H. 1984. Saurierfährten. Die neue Brehm-Bücherei 479: 231 pp., Wittenberg Lutherstadt: Ziemsen.

Hendricks, A. 1981. Die Saurierfährten von Münchehagen bei RehburgLoccum (NW-Deutschland). Abhandlungen aus dem Landesmuseum für Naturkunde zu Münster in Westfalen 43: 1-22.

Hiltermann, H. 1949. Funde von bernsteinartigen Harzen in der Unterkreide Nordwestdeutschlands. Schriften des Naturwissenschaftlichen Vereins für Schleswig-Holstein 24(1): 70-73.

Hoffmann, F. 1830. Uebersicht der orographischen und geognostischen Verhältnisse vom nordwestlichen Deutschland. Leipzig: J.A. Barth.

Hornung, J.J., and M. Reich. 2006. The "Wealden" collection of Max Ballerstedt (1857-1945) - undisclosed treasures from the Early Cretaceous of northwestern Germany. In 76. Jahrestagung der Paläontologischen Gesellschaft. Kiel, 28.-30. August 2006. Beitragskurzfassungen. Berichte-Reports des Instituts für Geowissenschaften, Christian-Albrechts-Universität Kiel 22:40-41.

Hornung, J.J., and M. Reich. 2007. Krokodile, Schildkröten \& Dinosaurier. Die "Wealden"-Sammlung der Universität Göttingen. Fossilien 24(1): 32-36.

Hornung, J.J., J. König, and M. Reich. 2007. Rediscovered type material of the ankylosaurian ichnospecies Metatetrapous valdensis Nopcsa, 1923 (Early Cretaceous, NW Germany). In Fossile Ökosysteme. 77. Jahrestagung der Paläontologischen Gesellschaft. Kurzfassungen der Vorträge und Poster, eds. O. Elicki, and J.W. Schneider. Wissenschaftliche Mitteilungen, Institut für Geologie, TU Bergakademie Freiberg 36: 59-60.

Hornung, J.J., Karl, H.-V., and Reich, M. 2008. An exquisitely preserved turtle footprint from the Berriasian (lowermost Cretaceous) of northwestern Germany. In Jahrestagung der Paläontologischen Gesellschaft. 8.-10. September 2008, Erlangen, eds. S.B. Löffler, and A. Freiwald. Erlanger geologische Abhandlungen, Sonderband 6: 91-92.

Huckriede, R. 1967. Molluskenfaunen mit limnischen und brackischen Elementen aus Jura, Serpulit und Wealden NW-Deutschlands und ihre paläogeographische Bedeutung. Beihefte zum Geologischen Jahrbuch 67: 263 pp.

Hulke, R. 1980. Mit raumgreifenden Schritten stapfte der Dinosaurier über das Meer-Ufer. Die Harke (29 Nov 1980), without pagination, Nienburg/Weser. (local newspaper).

Jaffé, G. 1912. Über Pholidosaurusreste aus dem Naturhistorischen Museum in Lübeck. Mitteilungen der Geographischen Gesellschaft und des Naturhistorischen Museums in Lübeck (Zweite Reihe) 25: 1-10.

Jordan, H. 1979. Erläuterungen zu Blatt Nr. 3521 Rehburg. In Geologische Karte von Niedersachsen, ed. Niedersächsisches Landesamt für Bodenforschung, 134 pp., Hannover: Landesamt für Bodenforschung.

Kästner, M., I. Schülke, and J. Winsemann. 2008. Facies architecture of a Late Jurassic carbonate ramp: the Korallenoolith of the Lower Saxony Basin. International Journal of Earth Sciences 97(5): 991-1011.

Karl, H.-V., A. Gehler, V.J. Roden, and M. Reich. 2007a. Die Schildkröten des nordwestdeutschen "Wealden" (Unter-Kreide: Berriasium) und ihre Paläoökologie. In Fossile Ökosysteme. 77. Jahrestagung der Paläontologischen Gesellschaft. Kurzfassungen der Vorträge und Poster, eds. O. Elicki, and J.W. Schneider. Wissenschaftliche Mitteilungen, Institut für Geologie, TU Bergakademie Freiberg 36:64-65.

Karl, H.-V., U. Staesche, G. Tichy, and S. Peitz. 2007b. Systematik der Schildkröten (Anapsida: Chelonii) aus Oberjura und Unterkreide von Nordwestdeutschland. In Fossile Schildkröten aus vier Ländern in drei Kontinenten, coord. U. Staesche. Geologisches Jahrbuch (B: Regionale Geologie Ausland) 98: 5-89.

Kauenhowen, W. 1927. Die Faziesverhältnisse und ihre Beziehung zur Erdölbildung an der Wende Jura - Kreide in 
Nordwestdeutschland. Neues Jahrbuch für Mineralogie etc. (B: Geologie und Paläontologie), Beilagen-Band 58: 215-272.

Kemper, E. 1973. Das Berrias (tiefe Unterkreide) in NW-Deutschland. Geologisches Jahrbuch (A: Allgemeine und regionale Geologie BR Deutschland und Nachbargebiete, Tektonik, Stratigraphie, Paläontologie) 9: 47-67.

Kemper, E. 1992. Die tiefe Unterkreide im Vechte-Dinkel-Gebiet (westliches Niedersächsisches Becken). Losser: Stichting het Starinmonument te Losser.

Kleinschmidt, G. 1986. Die Dinosaurierspuren der BückebergFormation in den Rehburger Bergen bei Münchehagen (NW-Deutschland). Unpublished Diploma thesis, University of Münster, 108 pp., Münster.

Koken, E. 1883. Die Reptilien der norddeutschen unteren Kreide. Zeitschrift der Deutschen Geologischen Gesellschaft 35: 735-827.

Koken, E. 1886. Vorkommen fossiler Crocodiliden in den Wealdenbildungen Norddeutschlands und über die Systematik der mesozoischen Crocodiliden. Zeitschrift der Deutschen Geologischen Gesellschaft 38: 664-670.

Koken, E. 1887. Die Dinosaurier, Crocodiliden und Sauropterygier des norddeutschen Wealden. Palaeontologische Abhandlungen 3(5): $1-111$.

Koken, E. 1896. Die Reptilien des norddeutschen Wealden. Nachtrag. Palaeontologische Abhandlungen 7: 119-126. (=N.F. 3 (2)).

Kuhn, O. 1958. Die Fährten der vorzeitlichen Amphibien und Reptilien. Bamberg: Meisenbach.

Kvale, E.P., A.D. Johnson, D.L. Mickelson, K. Keller, L.C. Furer, and A.W. Archer. 2001. Middle Jurassic (Bajocian and Bathonian) Dinosaur Megatracksites, Big Horn Basin, Wyoming, U.S.A. Palaios 16(3): 233-254.

LBEG [Landesamt für Bergbau, Energie und Geologie Niedersachsen] 2009. Cardomap server, http://memas01.lbeg.de/lucidamap/ index.asp [last accessed 02 Jul 2009].

Lehmann, J. 2003. Dinosaurierfährten aus dem Obernkirchener Sandstein (Unterkreide, Berriasium) in der Geowissenschaftlichen Sammlung der Universität Bremen. Abhandlungen des Naturwissenschaftlichen Vereins zu Bremen 45: 473-486.

Lehmann, J. 2006. Dinosaurier-Spuren einer vergangenen Welt. Münchehagen, der Bremer Stein und die Saurierfährten. Haus der Wissenschaft e. V. 3: 1-91.

Lehmann, J., M. Krogmann, U. Richter, and A. Broschinski. 2006. Neue Dinosaurierfährten vom Rang eines Naturdenkmals in den Sandsteinen der Bückeberg Formation (Unterkreide, Berriasium) von Münchehagen, Niedersachsen. Abhandlungen des Naturwissenschaftlichen Vereins zu Bremen 46: 27-37.

Lehmann, U. 1978. Eine Platte mit Fährten von Iguanodon aus dem Obernkirchener Sandstein (Wealden). Mitteilungen aus dem Geologisch-Paläontologischen Institut der Universität Hamburg 48: $101-114$

Lessertisseur, J. 1955. Traces fossiles d'activite animale et leur signification paleobiologique. Mémoires de la Société Géologique de France (Nouvelle Série) 34(74): 1-148.

Lill, K., and W. Riegel. 1991. Ein fluviatil dominiertes Delta im „Unteren Wealden“(Berrias, Bueckeberg-Folge) von Borgloh/ Kloster Ösede, Osnabrücker Hügelland, Niedersachsen). Bericht der Naturhistorischen Gesellschaft Hannover 133: 221-255.

Lipps, T. 1923. Ueber die Unter-Kreide-Flora Nordwest-Deutschlands, besonders die Flora des Barrémien von Hildesheim. Botanisches Archiv 4(5): 329-381.

Lockley, M.G. 1991a. Tracking Dinosaurs: A new Look at an Ancient World. Cambridge, MA: Cambridge University Press.

Lockley, M.G. 1991b. The Moab Megatracksite: A preliminary description and discussion of millions of Middle Jurassic tracks in eastern Utah. In Guidebook for Dinosaur Quarries and Tracksites Tour, Western Colorado and Eastern Utah, ed. W.R.
Averett, 59-65. Grand Junction, CO: Museum of Western Colorado.

Lockley, M.G. 1993. Auf den Spuren der Dinosaurier. Dinosaurierfährten-Eine Expedition in die Vergangenheit. Basel: Birkhäuser.

Lockley, M.G. 1997. The paleoecological and paleoenvironmental utility of Dinosaur tracks. In The complete Dinosaur, ed. J.O. Farlow, and M.K. Brett-Surman, 554-578. Bloomington, IN: Indiana University Press.

Lockley, M.G. 2000. An amended description of the theropod footprint Bueckeburgichnus maximus Kuhn 1958, and its bearing on the megalosaur tracks debate. Ichnos 7(3): 217-225.

Lockley, M.G., and C.A. Meyer. 2000. Dinosaur tracks and other fossil footprints of Europe. New York: Columbia University Press.

Lockley, M.G., and J.G. Pittman. 1989. The megatracksite phenomenon: Implications for paleoecology, evolution and stratigraphy. Journal of Vertebrate Paleontology 9(3): 30A.

Lockley, M.G., A. Hunt, J. Holbrook, M. Matsukawa, and C. Meyer. 1992. The dinosaur freeway: A preliminary report on the Cretaceous megatracksite, Dakota Group, Rocky Mountain Front Range and High Plains, Colorado, Oklahoma and New Mexico. In Mesozoic of the Western Interior, ed. R. M. Flores. SEPM Midyear Meeting Field Guidebook (1992): 39-54, Fort Collins, Colo. [Theme Meeting 17.-19.08.1992, Rocky Mountain Section SEPM].

Lockley, M.G., J.O. Farlow, and C.A. Meyer. 1994. Brontopodus and Parabrontopodus ichnogen. nov. and the significance of wideand narrow-gauge sauropod trackways. Gaia 10: 135-145.

Lockley, M.G., C.A. Meyer, and V.F. dos Santos. 1998. Megalosauripus and the problematic concept of megalosaur footprints. In Aspects of Theropod Paleobiology, eds. B.P. Pélaez-Moreno, T. Holtz jr., J.L. Sanz, and J. Moratalla. Gaia 15:313-337.

Lockley, M.G., J.L. Wright, and D. Thies. 2004. Some observations on the dinosaur tracks at Münchehagen (Lower Cretaceous), Germany. Ichnos 11(3-4): 261-274.

Look, E.-R. 1986. Dinosaurierfährten von Münchehagen im Landkreis Nienburg, 15 pp., Nienburg.

Look, E.-R., S. Kulle-Battermann, and R. Töneböhn. 1988. Die Dinosaurierfährten von Münchehagen (Landkreis Nienburg/ Weser) im Naturpark "Steinhuder Meer", 20 pp., Hannover: Naturhistorische Gesellschaft.

López-Arbarello, A., M. Reich, and A. Gehler. 2007. New specimen of "Lepidotes" mantelli Agassiz, 1833 from the German "Wealden" and the taxonomy of the giant "Lepidotes" of Europe. In Fossile Ökosysteme. 77. Jahrestagung der Paläontologischen Gesellschaft. Kurzfassungen der Vorträge und Poster, eds. O. Elicki, and J.W. Schneider. Wissenschaftliche Mitteilungen, Institut für Geologie, TU Bergakademie Freiberg 36: p. 92.

Mägdefrau, K., and H. Rudolf. 1969. Morphologie und Histologie der Nadel der Conifere Abietites linkii (Roem.) Dunk. aus dem Wealden des Hils. Neues Jahrbuch für Geologie und Paläontologie, Monatshefte 5: 288-298.

Mantell, G.A. 1825. Notice on the Iguanodon, a newly discovered Fossil Reptile, from the Sandstone of Tilgate Forest, in Sussex. Philosophical Transactions of the Royal Society of London 115(2): 179-186.

Martin, G.P.R. 1940. Ostracoden des norddeutschen Purbeck und Wealden. Senckenbergiana 22: 275-361.

Martin, G.P.R. 1958. Über die systematische Stellung der Gattung Cypridea Bosquet (Ostracoda), nebst Beschreibung der Wealden-Basis-Ostracode C. buxtorfi n. sp. Neues Jahrbuch für Geologie und Paläontologie, Monatshefte 7: 312-320.

Martin, G.P.R. 1961a. Eine marine Mikrofauna im Wealden von Emlichheim (Emsland, NW-Deutschland. Palaeontographica (A. Paläozoologie, Stratigraphie) 116: 105-120. 
Martin, G.P.R. 1961b. Die Gattung Fabanella n. g. (Ostracoda) im NW-deutschen Malm und Wealden. Senckenbergiana Lethaea 42(3/4): 181-195.

Martin, G.P.R., and W. Weiler. 1954. Fisch-Otolithen aus dem deutschen Mesozoikum (Dogger bis Wealden). Senckenbergiana Lethaea 35(3/4): 119-182.

Marty, D., A. Strasser, and C.A. Meyer. 2009. Formation and taphonomy of human footprints in microbial mats of present-day tidal-flat environments: Implications for the study of fossil footprints. Ichnos 16(1-2): 127-142.

Meyer, C.A. 1993. A sauropod dinosaur megatracksite from the Late Jurassic of northern Switzerland. Ichnos 3(1): 29-38.

Meyer, D. 1987. Naturdenkmal Saurierfährten von Münchehagen. Fossilien 4(3): 142-143.

Mutterlose, J. 1997a. Lower Cretaceous. In Cretaceous Depositional Environments of NW Germany, eds. J. Mutterlose, M.G.E. Wippich, and M. Geisen. Bochumer Geologische und Geotechnische Arbeiten 46: 7-12.

Mutterlose, J. 1997b. Münchehagen quarry. In Cretaceous depositional environments of NW Germany, eds. J. Mutterlose, M.G.E. Wippich, and M. Geisen. Bochumer Geologische und Geotechnische Arbeiten 46: 123-128.

Mutterlose, J. 2000. Unterkreide im Niedersächsischen Becken. In Die Kreide der Bundesrepublik Deutschland, ed. Stratigraphische Kommission Deutschlands. Courier Forschungsinstitut Senckenberg 226: 79-101.

Mutterlose, J., and A. Bornemann. 2000. Distribution and facies patterns of Lower Cretaceous sediments in northern Germany: a review. Cretaceous Research 21(6): 733-759.

Naumann, E. 1927. Blatt Eldagsen, Nr. 2088. Erläuterungen zur geologischen Karte von Preußen und benachbarten deutschen Ländern 265: $57 \mathrm{pp}$.

Nopcsa, F. 1923. Die Familien der Reptilien. Fortschritte der Geologie und Palaeontologie 1 (2): 210 pp.

Norman, D.B. 2004. Basal Iguanodontia. In The Dinosauria, ed. D.B. Weishampel, P. Dodson, and H. Osmolska, 413-437. Berkeley, CA: University of California Press.

Nyhuis, C. and Herbig, H.-G. 2009. Ichthyolithe aus dem Berriasium von Gronau/Westfalen (westliches Niedersächsisches Kreidebecken)—Rekonstruktion einer trophischen Kette aus sturmkondensierten Bonebeds. In Paläontologie - Schlüssel zur Evolution. 79. Jahrestagung der Paläontologischen Gesellschaft. Kurzfassungen der Tagungsbeiträge, eds. T. Martin, and S.I. Kaiser. Terra Nostra. Schriften der Alfred-Wegener-Stiftung 2009/3: p. 85.

Owen, R. 1842. Report on British Fossil Reptiles. Part II. Report of the Annual Meeting of the British Association for the Advancement of Science 12: 60-204.

Paul, G. 2008. A revised taxonomy of the iguanodont dinosaur genera and species. Cretaceous Research 29(2): 192-216.

Pelzer, G. 1984. Cross section through a fluvial environment in the Wealden of Northwest Germany. In Short papers. Third symposium on Mesozoic terrestrial ecosystems, ed. W.-E. Reif, and F. Westphal, 181-186. Tübingen: Attempto Verlag.

Pelzer, G. 1987. Transition from fluvial to littoral environments in the Wealden facies (lower most Cretaceous) of Northwest Germany. In Short papers. 4. Symposium on Mesozoic Terrestrial Ecosystems, eds. P.J. Currie, and E.H. Koster. Occasional Paper of the Tyrell Museum of Palaeontology 3: 177-182.

Pelzer, G. 1998. Sedimentologie und Palynologie der Wealden-Fazies im Hannoverschen Bergland. Courier Forschungsinstitut Senckenberg 207: $211 \mathrm{pp}$.

Pelzer, G., and V. Wilde. 1987. Klimatische Tendenzen während der Ablagerung der Wealden-Fazies in Nordwesteuropa. Geologisches Jahrbuch (A: Allgemeine und regionale Geologie BR Deutschland und Nachbargebiete, Tektonik, Stratigraphie, Paläontologie) 96: 239-263.
Pelzer, G., Riegel, W., and V. Wilde. 1992. Depositional controls on the Lower Cretaceous Wealden coals of northwest Germany. In Controls on the Distribution and Quality of Cretaceous Coals, eds. P.J. McCabe, and J.T. Parrish. Geological Society of America, Special Paper 267: 227-244.

Peitz, S. 1998. Schildkröten der deutschen Wealden-Fazies - Ein Einblick in die Ballerstedtsche Sammlung. In 2. Treffen der deutschsprachigen Paläoherpetologen, Tübingen 27.02.01.03.1998. Extended Abstracts, eds. M.W. Maisch, and A.T. Matzke, 12-18, Tübingen.

Probst, E., and R. Windolf. 1993. Dinosaurier in Deutschland. München: Bertelsmann.

Richter, A., and U. Stratmann. 2007. Obernkirchener Sandsteinbrüche auf dem Bückeberg. Naturwerksteine und Fossilien der Unterkreidezeit. In Niedersächsisches Landesamt für Bergbau, Energie und Geologie, Geotope 109: 2 pp., Hannover. available online at http://www.lbeg.de/extras/geologie/downloads/geotope/ Nr_109_obernkirchen_bueckeberg.pdf [last accessed 24 Feb 2009].

Richter, A., O. Wings, U. Richter, and N. Knötschke. 2007. "Happy Feet": A new Lower Cretaceous dinosaur tracksite from Münchehagen, Germany. Journal of Vertebrate Paleontology 27(3): 134A.

Richter, A., A. Böhme, and T. van der Lubbe. 2009. "Chicken Run": A new unusual, heavily dinoturbated tracksite from the Lower Cretaceous sandstones of Obernkirchen, northern Germany. Journal of Vertebrate Paleontology 29(3): 171A.

Richter, U. 2007. Dinosaurier-Freilichtmuseum und Naturdenkmal Saurierfährten Münchehagen. Rehburg-Loccum: Dino-Park Münchehagen.

Richter, U., A. Richter, and J. Lehmann. 2007. Fährtensucher auf der Dinospur in den Rehburger Bergen. Fossilien 24(1): 11-20.

Riegel, W., and K. Lill. 1988. Geologische und sedimentologische Untersuchungen im Berrias von Borgloh/Kloster Ösede (Osnabrücker Hügelland, Niedersachsen). Nachrichten der Deutschen Geologischen Gesellschaft 39: 78-79.

Riegel, W., and V. Wilde. 1984. Biota and sedimentology of a fluvial environment in the Wealden of Northwest Germany; implications for ecosystem reconstruction. In Short papers. Third symposium on Mesozoic terrestrial ecosystems, ed. W.-E. Reif, and F. Westphal, 199-200. Tübingen: Attempto Verlag.

Riegel, W., G. Pelzer, and V. Wilde. 1986. Erste Ergebnisse einer paläobotanischen Grabung in der fluviatilen Wealden-Fazies des Osterwaldes bei Hannover. Courier Forschungs-Institut Senckenberg 86: 137-170.

Roemer, F.A. 1836. Die Versteinerungen des Norddeutschen Oolithen-Gebirges. Hannover: Hahn.

Sachs, S. 1997. Erster Nachweis eines gepanzerten Dinosauriers (Reptilia, Ornithischia, Thyreophora) aus der Unterkreide von Gronau in Westfalen. Neues Jahrbuch für Geologie und Paläontologie, Monatshefte 1: 56-64.

Salisbury, S.W., Willis, P.M.A., Peitz, S., and Sander, P.M. 1999. The crocodilian Goniopholis simus from the Lower Cretaceous of north-western Germany. In Cretaceous fossil vertebrates, D.M. Unwin. Special Papers in Palaeontology, 60: 121-148.

Sarjeant, W.A.S., J.B. Delair, and M.G. Lockley. 1998. The footprints of Iguanodon: a History and taxonomic study. Ichnos 6(3): 183-202.

Schmidt, H. 1959. Die Cornberger Fährten im Rahmen der Vierfüßler-Entwicklung. Abhandlungen des Hessischen Landesamtes für Bodenforschung 28: $137 \mathrm{pp}$.

Schmidt, H. 1969. Stenopelix valdensis H. v. Meyer, der kleine Dinosaurier des norddeutschen Wealden. Paläontologische Zeitschrift 43(3-4): 194-198.

Schott, W., W. Jaritz, F. Kockel, C.W. Sames, U. von Stackelberg, J. Stets, D. Stoppel, R. Baldschuhn, and K.-D. Krampe. 1967. Paläogeographische Karten von Nordwestdeutschland im 
Maßstab 1:200000. In Paläogeographischer Atlas der Unterkreide von Nordwest-Deutschland mit einer Übersichtsdarstellung des nördlichen Mitteleuropa, ed. Bundesanstalt für Bodenforschung, 289 pp., Hannover: Bundesanstalt für Bodenforschung.

Schott, W., W. Jaritz, F. Kockel, C.W.Sames, U. von Stackelberg, J. Stets, D. Stoppel, R. Baldschuhn, and K.-D. Krampe. 1969. Erläuterungen. In: Bundesanstalt für Bodenforschung (ed.): Paläogeographischer Atlas der Unterkreide von NordwestDeutschland mit einer Übersichtsdarstellung des nördlichen Mitteleuropa. 315 pp., Hannover: Bundesanstalt für Bodenforschung.

Schudack, M. 1996. Die Charophyten des Niedersächsischen Beckens (Oberjura - Berriasium): Lokalzonierung, überregionale Korrelation und Palökologie. Neues Jahrbuch für Geologie und Paläontologie, Abhandlungen 200(1/2): 27-52.

Schudack, U., and M. Schudack. 2009. On the taxonomy of the species Cypridea setina Anderson, 1939 and Cypridea laevigata Dunker, 1846 (Ostracoda, Crustacea) from the Early Cretaceous of Europe-a special note on systematical inconsistencies. Berliner paläobiologische Abhandlungen 10: 311-320.

Schultze, H.-P. 1970. Indaginilepis rhombifera $\mathrm{n}$. gen. et n. sp., ein altertümlicher Palaeoniscoide (Pisces, Actinopterygii) aus dem Wealden von Norddeutschland. Paläontologische Zeitschrift 44(1-2): 10-24.

Schwennicke, T. 1998. Sedimenttexturen und Lebensspuren der Sohlbank des Naturdenkmals "Saurierfährten Münchehagen". Mitteilungen aus dem geologischen Institut der Universität Hannover 37: 61-102.

Staesche, U. 1981. Die Saurierfährten von Münchehagen. Führer zu vor- und frühgeschichtlichen Denkmälern 49: 146-149.

Stechow, E. 1909. Neue Funde von Iguanodon-Fährten. Centralblatt für Mineralogie, Geologie und Paläontologie (1909): 700-705.

Strauss, C., F. Elstner, J. Du Chène, J. Mutterlose, H. Reiser, and K.-H. Brandt. 1993. New micropalaeontological and palynological evidence on stratigraphic position of the "German Wealden" in NW-Germany. Zitteliana 20: 389-401.

Struckmann, C. 1880a. Die Wealden-Bildung der Umgebung von Hannover. Eine geognostisch-paläontologisch-statistische Darstellung. Hannover: Hahn.

Struckmann, C. 1880b. Vorläufige Nachricht über das Vorkommen großer, vogelähnlicher Thierfährten (Ornithoidichnites) im Hastingssandsteine von Bad Rehburg bei Hannover. Neues Jahrbuch für Mineralogie, Geologie und Paläontologie 1: 125-128.

Struckmann, C. 1894. Über einen Zahn des Iguanodon aus dem Wealden von Sehnde bei Lehrte. Zeitschrift der Deutschen Geologischen Gesellschaft 156: 828-831.

Sues, H.-D., and P.M. Galton. 1982. The systematic position of Stenopelix valdensis (Reptilia: Ornithischia) from the Wealden of north-western Germany. Palaeontographica (A: Paläozoologie, Stratigraphie) 178: 183-190.

Thulborn, R.A. 2001. History and nomenclature of the theropod dinosaur tracks Bueckeburgichnus and Megalosauripus. Ichnos 8(3-4): 207-222.

Töneböhn, R., and S. Kulle-Battermann. 1989a. Die Dinosaurierfährten von Münchehagen. Teil A. Zur Paläontologie der Saurierfährten von Münchehagen. Unpublished report, 108 pp., Nienburg/Weser: Amt für Regionalplanung.

Töneböhn, R., and S. Kulle-Battermann. 1989b. Die Dinosaurierfährten von Münchehagen. Teil B. Maßnahmen zum Erhalt des Naturdenkmals "Saurierfährten Münchehagen". Unpublished report, 70 pp., Nienburg/Weser: Amt für Regionalplanung.

Töneböhn, R., and S. Kulle-Battermann. 1989c. Die Dinosaurierfährten von Münchehagen. Teil C. Vorschläge zur weiteren musealen Gestaltung des Naturdenkmals "Saurierfährten Münchehagen". Unpublished report, 70 pp., Nienburg/Weser: Amt für Regionalplanung. van der Lubbe, T., A. Richter, and A. Böhme. 2009. Velociraptor's sisters: First report of troodontid tracks from the Lower Cretaceous of northern Germany. Jounal of Vertebrate Paleontology 29(3): 194A.

von Meyer, H. 1841. Pholidosaurus schaumburgensis, ein Saurus aus dem Sandstein der Wald-Formation Nord-Deutschlands. Neues Jahrbuch für Mineralogie, Geognosie, Geologie und Petrefakten-Kunde 1841: 443-445.

von Meyer, H. 1846. Reptilien aus der Wealdenformation Norddeutschlands. In: Dunker, W. (ed.): Monographie der Norddeutschen Wealdenbildung: ein Beitrag zur Geognosie und Naturgeschichte der Vorwelt. 70-83, Braunschweig.

von Meyer, H. 1851. Ctenochasma Roemeri. Palaeontographica 2(3): 82.

von Meyer, H. 1857. Beiträge zur näheren Kenntnis fossiler Reptilien. Neues Jahrbuch für Mineralogie, Geologie und Paläontologie (1857): 532-543.

von Meyer, H. 1859. Stenopelix Valdensis, ein Reptil aus der WealdenFormation Deutschlands. Palaeontographica 7(1): 25-34.

Waldeck, H. 1969. Gefügeuntersuchungen in Wealdenkonglomeraten des Osterwaldes und Nesselberges südlich Hannover. Geologisches Jahrbuch 87: 229-275.

Wegner, T. 1913. Geologie Westfalens und der angrenzenden Gebiete, 1st ed. Paderborn: Schöningh.

Wegner, T. 1914. Brancasaurus brancai n. gen. n. sp., ein Elasmosauride aus dem Wealden Westfalens. In Wilhelm Branca zum siebzigsten Geburtstage, 9. Sept. 1914. Eine Festschrift seiner Schüler, ed. F. Schöndorf, 235-305, Leipzig: Borntraeger.

Wegner, T. 1926. Geologie Westfalens und der angrenzenden Gebiete, 2nd ed. Paderborn: Schöningh.

Wellnhofer, P. 1991. The illustrated Encyclopedia of Pterosaurs. New York: Crecent Books.

Wilde, V. 1991. Tritaenia (al. Abietites) linkii (Roemer) Mägdefrau \& Rudolf (Coniferae inc. sed.) und ihr Vorkommen in der Wealden-Fazies der unteren Kreide von Nordwestdeutschland. Neues Jahrbuch für Geologie und Paläontologie, Abhandlungen 183(1-3):363-374.

Wilde, V., and C. Heunisch. 1990. Auftreten und Erhaltung von Moosen im Mesozoikum (Keuper und Wealden) Nordwestdeutschlands. Nachrichten der Deutschen Geologischen Gesellschaft 43: 155.

Wilde, V., and S. Schultka. 1996. Die sandige Wealden-Fazies (Bückeberg-Formation, Berrias, Unterkreide) am Westrand eines Schüttungskörpers bei Osnabrück (NW-Deutschland). Neues Jahrbuch für Geologie und Paläontologie, Abhandlungen 199(2): 249-268.

Wilde, V., D. Thies, and W. Riegel. 1995. Exkursion D. Terrestrische Paläo-Ökologie im Wealden des Hannoverschen Berglandes. In Geologie und Paläontologie im Raum Hildesheim. Exkursionen aus Anlaß der 65. Jahrestagung der Paläontologischen Gesellschaft in Hildesheim 1995, eds. M. Boetzkes, and J. Vespermann. Terra Nostra. Schriften der Alfred-Wegener-Stiftung 95/5: 125-151.

Windolf, R. 1998. Dinosaurierfunde in Niedersachsen. Arbeitskreis Paläontologie Hannover 26(1): 1-7.

Wings, O., N. Schulze, N. Knötschke, and A. Broschinski. 2005a. Neue Dinosaurierfährten aus der Niedersächsischen Unterkreide. GMit, Geowissenschaftliche Mitteilungen 20: 33-35.

Wings, O., A. Broschinski, and N. Knötschke. 2005b. New theropod and ornithopod dinosaur trackways from the Berriasian of Münchehagen (Lower Saxony, Germany. In Current Research in Vertebrate Palaeontology 3rd Annual Meeting of the European Association of Vertebrate Palaeontologists (EAVP). Kaupia. Darmstädter Beiträge zur Naturgeschichte 14: 105.

Wolburg, J. 1949. Ergebnisse der Biostratigraphie nach Ostracoden im nordwestdeutschen Wealden. In Erdöl und Tektonik in 
Nordwestdeutschland, ed. A. Bentz, 349-360. Hannover: Amt für Bodenforschung.

Wolburg, J. 1959. Die Cyprideen des NW-deutschen Wealden. Senckenbergiana Lethaea 40(3/4): 223-315.

Wolburg, J. 1962. Zur Taxionomie und Nomenklatur einiger im Handbuch „Leitfossilien der Mikropalaeontologie“(1962) dargestellten Wealden-Ostracoden. Senckenbergiana Lethaea 43(6): $529-532$.
Wolburg, J. 1971. Zur Taxonomie und Nomenklatur einiger WealdenOstracoden. Senckenbergiana Lethaea 52(1): 39-46.

Wright, J.L. 2005. Steps in understanding sauropod biology: The importance of sauropod tracks. In The sauropods-Evolution and paleobiology, ed. K.C. Rogers, and J.A. Wilson, 252-284. Berkeley, CA: University of California Press. 